\title{
Strategies to Inhibit Hepatitis B Virus at the Transcript Level
}

\author{
Bingqian Qu ${ }^{1,2, *(D)}$ and Richard J. P. Brown ${ }^{1, *(D)}$ \\ 1 Division of Veterinary Medicine, Paul Ehrlich Institute, 63225 Langen, Germany \\ 2 European Virus Bioinformatics Center, 07743 Jena, Germany \\ * Correspondence: Bingqian.Qu@pei.de (B.Q.); Richard.Brown@pei.de (R.J.P.B.)
}

check for

updates

Citation: Qu, B.; Brown, R.J.P. Strategies to Inhibit Hepatitis B Virus at the Transcript Level. Viruses 2021, 13, 1327. https://doi.org/10.3390/ v13071327

Academic Editor: Carla S. Coffin

Received: 5 June 2021

Accepted: 6 July 2021

Published: 9 July 2021

Publisher's Note: MDPI stays neutral with regard to jurisdictional claims in published maps and institutional affiliations.

Copyright: (c) 2021 by the authors. Licensee MDPI, Basel, Switzerland. This article is an open access article distributed under the terms and conditions of the Creative Commons Attribution (CC BY) license (https:// creativecommons.org/licenses/by/ $4.0 /)$.

\begin{abstract}
Approximately 240 million people are chronically infected with hepatitis B virus (HBV), despite four decades of effective HBV vaccination. During chronic infection, HBV forms two distinct templates responsible for viral transcription: (1) episomal covalently closed circular (ccc)DNA and (2) host genome-integrated viral templates. Multiple ubiquitous and liver-specific transcription factors are recruited onto these templates and modulate viral gene transcription. This review details the latest developments in antivirals that inhibit HBV gene transcription or destabilize viral transcripts. Notably, nuclear receptor agonists exhibit potent inhibition of viral gene transcription from cccDNA. Small molecule inhibitors repress HBV X protein-mediated transcription from cccDNA, while small interfering RNAs and single-stranded oligonucleotides result in transcript degradation from both cccDNA and integrated templates. These antivirals mediate their effects by reducing viral transcripts abundance, some leading to a loss of surface antigen expression, and they can potentially be added to the arsenal of drugs with demonstrable anti-HBV activity. Thus, these candidates deserve special attention for future repurposing or further development as anti-HBV therapeutics.
\end{abstract}

Keywords: chronic hepatitis B; covalently closed circular DNA; viral integration; transcription factor; nuclear receptor; transcriptional inhibitor; RNA interference

\section{Introduction}

In the past decade, global deaths from viral hepatitis have increased to become the seventh leading cause of mortality, annually causing more deaths than AIDS, diabetes, and tuberculosis (1.4 million/year) [1]. Viral hepatitis results in liver inflammation and is caused by hepatotropic viruses, with both acute or chronic disease courses described. These liver-tropic pathogens represent a range of DNA and RNA viruses from diverse viral families with distinct modes of transmission: Hepatitis A virus (HAV), Hepatitis B virus (HBV), Hepatitis C virus (HCV), Hepatitis delta virus (HDV), and Hepatitis E virus (HEV). Both HCV and HBV can cause chronic infections in immune-competent individuals [2], potentially leading to progressive liver injury. According to the World Health Organization, $\mathrm{HBV}$ and HCV chronically infect 240 million and 71 million people, respectively. Chronic infections may ultimately result in liver fibrosis, cirrhosis, and hepatocellular carcinoma (HCC). Indeed, an estimated $75 \%$ of all HCC cases are attributed to chronic infection with $\mathrm{HBV}(\mathrm{CHB})$ or HCV [3,4].

\section{Basic HBV Molecular Biology}

Approximately $90 \%$ of HBV virions contain a double-stranded relaxed circular (rc)DNA genome of $\approx 3.2 \mathrm{~kb}$. Every rcDNA template consists of an intact minus strand covalently bound to a viral polymerase via phosphotyrosine and a partial plus strand [5]. The remaining $10 \%$ of HBV virions contain double-stranded linear (dsl)DNA genomes, which are generated from in situ priming of plus-strand synthesis [6]. Upon infection, rcDNA and dsIDNA genomes are converted into another form, covalently closed circular (ccc)DNA, by the host's nuclear DNA repair machinery [7]. The circular genome contains four promot- 
ers (core, preS, S, and X), two enhancers (EnhI and EnhII), and encodes four viral genes (precore-core, polymerase, preS-S, and X) [8].

CccDNA serves as a replicative template for all transcripts including precore mRNA, pregenomic (pg)RNA, preS, S, and X mRNA. All transcripts possess a polyadenylated $3^{\prime}$ terminus $[9,10]$. During replication, these transcripts are translated into seven viral proteins. Precore mRNA is translated and proteolytically processed to yield HBV e antigen (HBeAg), whereas pgRNA is not only reverse transcribed but also translated to form the viral polymerase and $\mathrm{HBV}$ core antigen ( $\mathrm{HBcAg})$ [11]. PreS and S mRNAs are translated into large-, middle-, and small-envelope proteins. X mRNA is translated to HBx protein [12].

PgRNA is bound to the viral polymerase, and this complex recruits HBcAg dimers for encapsidation [13]. Within nucleocapsids, rcDNA or dsIDNA are reverse transcribed into complementary pgRNA. This pgRNA template is then degraded via the RNase $\mathrm{H}$ activity of the viral polymerase [14]. Nucleocapsids interact with the envelope proteins, and virions are secreted. Envelope proteins can also be assembled to form non-infectious subviral particles, filaments, and spheres, which do not contain viral DNA genomes $[15,16]$.

\section{Approved Drugs and Potential Therapeutic Options against Chronic Hepatitis B}

Effective treatments for chronic $\mathrm{HCV}$ infection are now available and involve combination therapy with direct-acting antivirals (DAAs). DAAs targeting the NS3/4A protease (Voxilaprevir, Paritaprevir, Grazoprevir, Glecaprevir), the NS5A phoshoprotein (Ledipasvir, Velpatasvir, Ombitasvir, Elbasvir, Pibrentasvir), and the NS5B polymerase (Sofosbuvir, Dasabuvir) lead to a sustained virologic response, which is defined as undetectable HCV RNA at 12 weeks post-treatment [17-19]. The development of DAAs was initiated and facilitated using two methodologies: high-throughput screening utilizing HCV replicons [20,21] and crystal structures for the viral NS3, NS5A, and NS5B proteins [22-26]. In contrast, due to unresolved viral protein structures and low-throughput in vitro infection-based screening models, no 'magic bullet' antiviral treatment that cures $\mathrm{CHB}$ has been developed to date.

Currently, CHB is controlled but not cured by approved antivirals. For instance, transcriptionally active HBV DNA in the nucleus is not directly targeted [27]. Except for interferon- $\alpha(\operatorname{IFN}-\alpha)$ and pegylated IFN- $\alpha$, all other licensed drugs are nucleoside (Lamivudine, Clevudine, Entecavir, Telbivudine) and nucleotide analogues (Adefovir dipivoxil, Tenofovir disoproxil fumarate, Tenofovir alafenamide). All these drugs are potent at reducing viral loads and normalizing alanine transaminase levels in CHB patients. However, long-term treatment with many of these drugs leads to the development of multiple drug resistance mutations. In addition, while a limited reduction in cccDNA is achieved, long-term nucleos(t)ide analogue treatment does not reduce hepatitis $B$ surface antigen (HBsAg) levels [28-32].

Both virus and host druggable targets exist at multiple stages of the HBV life cycle, including viral entry, replication, assembly, and the secretion of subviral particles, which do not contain genomic material [33]. For example, myristoylated preS1-derived lipopeptide (Myrcludex B) specifically bound to the human sodium taurocholate cotransporting polypeptide (hNTCP), the bona fide HBV and HDV receptor, prevents HBV entry in urokinase-type plasminogen activator and severe immunodeficient (uPA-SCID) mice repopulated with primary human hepatocytes [34]. Myrcludex B also potently blocked HBV spreading from initially infected hepatocytes to uninfected cells [35]. Although HBsAg levels remained, HBV viral load was significantly decreased at week 24 in the pegylated IFN- $\alpha$-Myrcludex B cohort $(n=7)$ compared with Myrcludex B monotherapy $(n=8)$ in a phase $1 \mathrm{~b} / \mathrm{IIa}$ trial [36]. For HBV replication, the RNase $\mathrm{H}$ domain within viral polymerase has also been effectively targeted by specific inhibitors in previous preclinical trials [37-39].

The availability of high-resolution structures for HBV nucleocapsids has facilitated the development of multiple capsid allosteric modulators [40-42]. Recently, one leading compound, NVR 3-778, showed reduced HBV DNA and RNA levels in patient serum $(n=43)$ when administered as monotherapy, with a larger reduction observed in combination 
with pegylated IFN- $\alpha(n=10)$ [43]. Morphothiadin (GLS4), a derivative of heteroaryldihydropyrimidine targeting capsid maturation, showed a potent in vitro antiviral activity and tolerability in healthy participants $(n=8)$ when co-administered with Ritonavir, which boosted plasma concentrations of morphothiadin [44]. More recently, JNJ-56136379 (JNJ6379) showed good tolerability in treatment-naïve chronic HBV patients in a phase I study. Remarkably, $32 \%$ of patients (13/41) had undetectable HBV DNA levels at 4 weeks treatment, despite no alteration in HBsAg levels [45]. In another trial, ABI-H0731 showed safety at $300 \mathrm{mg} /$ day but non-specific side effects at higher doses in some participants. The treatment resulted in dose-dependent declines in both HBV DNA and RNA levels [46].

Two nucleic acid polymers were shown to inhibit the secretion of subviral particles. Both REP 2139 and REP 2165 were well tolerated and showed a substantial activity in treatment-naive patients. The combination of Tenovofir, pegylated IFN- $\alpha$, and REP promoted HBsAg seroconversion $(<0.05 \mathrm{IU} / \mathrm{mL})$ in $60 \%$ of patients $(24 / 40)$. During 48 weeks of follow-up, no viral rebound was observed in $35 \%$ of patients $(14 / 40)$ [47].

All lines of evidence detailed above demonstrate that HBV replication can be controlled, but a permanent cure has not been achieved. Notably, none of the above drugs (except IFN- $\alpha$ ) target transcriptionally active templates and decompose viral transcripts. Thus, transcriptionally active templates should be recognized as novel drug targets, and any new-class antivirals targeting this virus life-cycle stage could represent a potential therapeutic option against CHB. Indeed, taking advantage of authentic infection models that allow cccDNA-mediated replication, a number of candidates were identified that either inhibit transcription or impact on the stability of existing viral transcripts. From here onwards, this review chronicles the latest developments and discusses the potential effects of this new class of drugs that could represent components of new therapeutic regimens that have potential as a functional cure for CHB.

\section{Templates of Transcription: cccDNA and Integrants}

HBV chronicity depends on the persistence of two types of viral reservoir, episomal cccDNA and integrants. Upon infection, rcDNA in virions is imported into the nucleus. How rcDNA converts to cccDNA remains unclear, but this appears to solely require the host's DNA repair machinery [48]. The conversion requires multiple steps: removal of viral polymerase from rcDNA, removal of RNA primer region from the plus strand of proteinfree rcDNA, removal of redundant sequences from the minus strand, DNA elongation of both strands, and finally ligation of all DNA ends [49]. Specifically, the host cellular enzyme tyrosyl-DNA-phosphodiesterase 2 (TDP2) likely cleaves the Tyr-rcDNA bond and releases the viral polymerase [50]. Flap structure-specific endonuclease 1 (FEN1) is responsible for the removal of redundant rcDNA-specific structures [51]. Next, DNA polymerase $k$ and topoisomerases (I and II) catalyze filling in the gap in the plus strand DNA $[52,53]$. Similarly, polymerase $\alpha$ is involved in the repair of the minus strand during intracellular amplification of cccDNA [54]. Host DNA ligases (LIG1 and 3) mediate the ligation of DNA nicks on both strands, converting it to a closed-circular state, whereas the ligase 4 (LIG4) drives the conversion of dsIDNA to cccDNA via non-homologous end joining [55]. Using yeast-extract screening, Wei and Ploss identified five components essential for cccDNA conversion: proliferating cell nuclear protein, replication factor C complex, FEN1, DNA polymerase $\delta$, and LIG1 [56]. These data suggest that cccDNA synthesis depends solely on the host's machinery and requires the concerted action of multiple nuclear proteins and enzymes, which requires further characterization. Once formed, episomal cccDNA is maintained in the nucleus: cccDNA is long-lived and stable at low copy numbers in non-dividing hepatocytes but sensitive to cell mitosis [57,58].

Distinct from rcDNA, dsIDNA in $\approx 10 \%$ of nucleocapsids can be imported to the nucleus to form cccDNA containing a redundant insertion of 16 nucleotides, which can revert to wild-type cccDNA probably via homologous recombination. This was initially observed in duck hepatitis B virus (DHBV) infected ducklings [59]. Alternatively, dslDNA can be integrated into the host genome carrying double-stranded DNA breaks [60]. These integra- 
tions occur at rate of one integration per $10^{3}-10^{4}$ hepatocytes in ducklings infected with DHBV and woodchucks chronically infected with woodchuck hepatitis virus (WHV) [61,62] and one integration per $10^{4}$ hepatocytes/hepatoma cells that were infected in vitro with HBV [63]. Distinct from cccDNA, the HBV integrants are randomly distributed across all chromosomes and show stability during cell mitosis, as integration frequencies in rapidly growing duckling hepatocytes and dividing HepG2 ${ }^{\mathrm{NTCP}}$ cells post infection were not reduced $[61,63,64]$.

PgRNA, precore, and subgenomic (preS, S, and X) RNAs are all transcribed from cccDNA (Figure 1a). However, integrated DNA is not capable of producing the 3.5 kilobase pgRNA and precore mRNA. Nevertheless, both preS and $S$ transcripts are expressed by the integrated DNA (Figure 1b). Indeed, natural HBV integration was identified in the "Alexander" hepatoma cell line, PLC/PRF/5. Four complete and two partial HBV genomes were detected, one of which produces HBsAg, whereas pgRNAs for HBcAg were undetectable $[65,66]$. HBV integrations were also characterized in other two hepatoma cells, Hep3B (clone F1, 14, and 217) and L6EC3, suggesting that these hepatoma cells with HBV subgenomic integrations are capable of HBsAg production $[67,68]$. Of note, HBx transcripts are expressed from integration sites in tumor tissues and hepatoma cell lines [69,70]. Lacking a stop codon, the translation of HBx may extend and produce viralhost chimeric genes (e.g., HBx-long interspersed nuclear element (HBx-LINE)), which can promote hepatic damage [71,72].

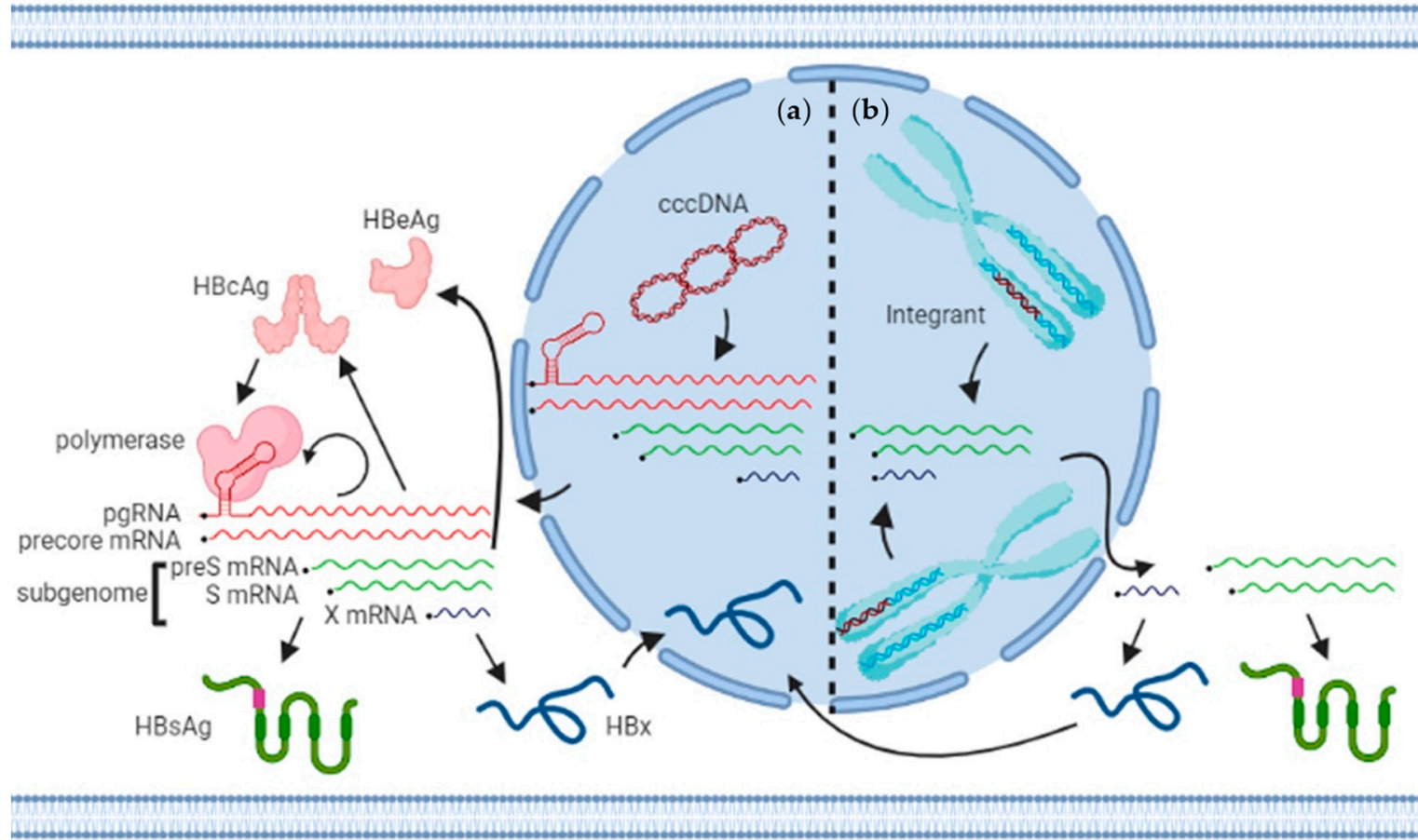

Figure 1. Overview of HBV transcription and translation from cccDNA and genomic integrants. (a) In the nucleus where cccDNA resides, RNA polymerase II-mediated transcription from cccDNA generates five capped and polyadenylated transcripts: pgRNA (3.5 kb), precore mRNA (3.5 kb), preS mRNA (2.4 kb), S mRNA (2.1 kb), and X mRNA (0.7 kb), all of which are exported into the cytoplasm. Seven viral proteins are translated from those transcripts (see text for details). (b) HBV subgenomic fragments are randomly integrated into different chromosomal locations. PreS/S and probably X transcripts are generated from integrated genomes and translated to HBsAg and HBx. So far, no evidence has emerged that that pgRNA and precore mRNA can also be produced in this manner. HBx is imported in the nucleus and functions as a transactivator on cccDNA. 


\section{Host and Viral Mediators of HBV Transcription}

Both stable DNA templates in hepatocytes can be constitutively transcribed. The architecture of the "HBV minichromosome" is composed of one cccDNA template coupled to viral core protein $(\mathrm{HBcAg})$, histones $(\mathrm{H} 3$ and $\mathrm{H} 4)$, and multiple host proteins [73]. This minimal complex was reconstituted in vitro and visualized using electron microscopy [74]. Using chromatin immunoprecipitation, the physical interaction between cccDNA and $\mathrm{HBcAg}$ or histones was confirmed [75]. The authors also reported that active cccDNAmediated transcription parallels the acetylation status of $\mathrm{H} 3$ and $\mathrm{H} 4$ histones and found that histone deacetylase inhibitors valproic acid and trichostatin A increase cccDNAbound acetylated histones and HBV transcription. Using deep sequencing of a purified nucleosome fraction, Tropberger et al. demonstrated that high levels of post-translationally modified histones are enriched at specific sites across the entire HBV genome and are associated with efficient transcription, whereas low levels of modified histones are required to bind cccDNA, which represses transcription at the promoters [76]. Regardless of its cccDNA binding capacity, the exact role of $\mathrm{HBcAg}$ in transcription from cccDNA remains unclear. HBcAg likely employs its C-terminal domain to maintain transcription and assist in the recruitment of histone acetyltransferases [77].

Efficient transcription requires both ubiquitously expressed and liver-specific transcription factors, as well as additional co-factors [78-80]. Host RNA polymerase II initiates cccDNA-mediated transcription. The essential and ubiquitous transcription factors, including IIB, TATA box protein, cAMP response element-binding transcription factor (CREB), CCAAT enhancer-binding protein (C/EBP), and nuclear factor kappa B (NF- $\mathrm{kB}$ ) not only enhance transcription from cccDNA but also cellular genes essential in cell differentiation, proliferation, and survival. Inhibitors targeting these would be not specific against HBV transcription and would likely induce unwanted effects on cells.

One of the largest families of liver-specific transcription factors, belonging to the nuclear receptor superfamily, is the hepatocyte nuclear factor (HNF). HNF1 $\alpha$ and other HNF1 members form homo/heterodimers, which increase the transcriptional activity of preS, $X$ promoters, and enhancer II activity [81-83]. When it activates the NF- $\mathrm{kB}$ pathway, HNF1 $\alpha$ in turn inhibits transcription [84]. HNF3 $\alpha / \beta / \gamma$ homo/heterodimers bind the preS promoter, enhancer I, enhancer II, and upregulate their transcriptional activity [85-87]. HNF $4 \alpha$ targets mainly the core promoter and enhances its transcription in hepatoma cells but not HeLa cells [88]. In contrast, liver-enriched HNF6 inhibits transcription of the S promoter but mediates no effects on other promoters or enhancers [89]. Currently, agonists and antagonists targeting any of the above HNFs are unavailable. It was discussed whether HNF $4 \alpha$ could represent a potential drug target as it contains a ligand-binding pocket [90]. How to position a drug specifically onto HNF proteins interacting with HBV cccDNA will be a major challenge in the future development of this potential class of inhibitors.

With forty-eight members, nuclear receptors (NRs) are the most abundant superfamily of transcriptional mediators in metazoans. They are mainly triggered by ligand-receptor interaction and function as transcription factors involved in cell proliferation, metabolism, and homeostasis [91]. NRs share a canonical structural organization with one or more variable transactivation domains. These include a conserved DNA-binding domain, a flexible hinge-containing nuclear localization signal, and a ligand-binding domain at the C-terminus. When they are stimulated by endogenous or exogenous ligands, the receptors dimerize either as homodimers or heterodimers (two proteins among the same subfamily, e.g., RAR $\alpha-R A R \beta)$. Frequently, they also form heterodimers with two components from different subfamilies (e.g., LXR $\beta-R X R \alpha, F X R-R X R$, PPAR $\gamma$-RXR, etc.), as shown in Figure 2a [92-94]. In terms of known binding profiles between the receptors and ligands, small molecules imitating the ligands can be simply generated by computer-aided drug design. Indeed, this feature makes NRs attractive as potential drug targets. The strategies for targeting NRs are described in detail in the following section. 


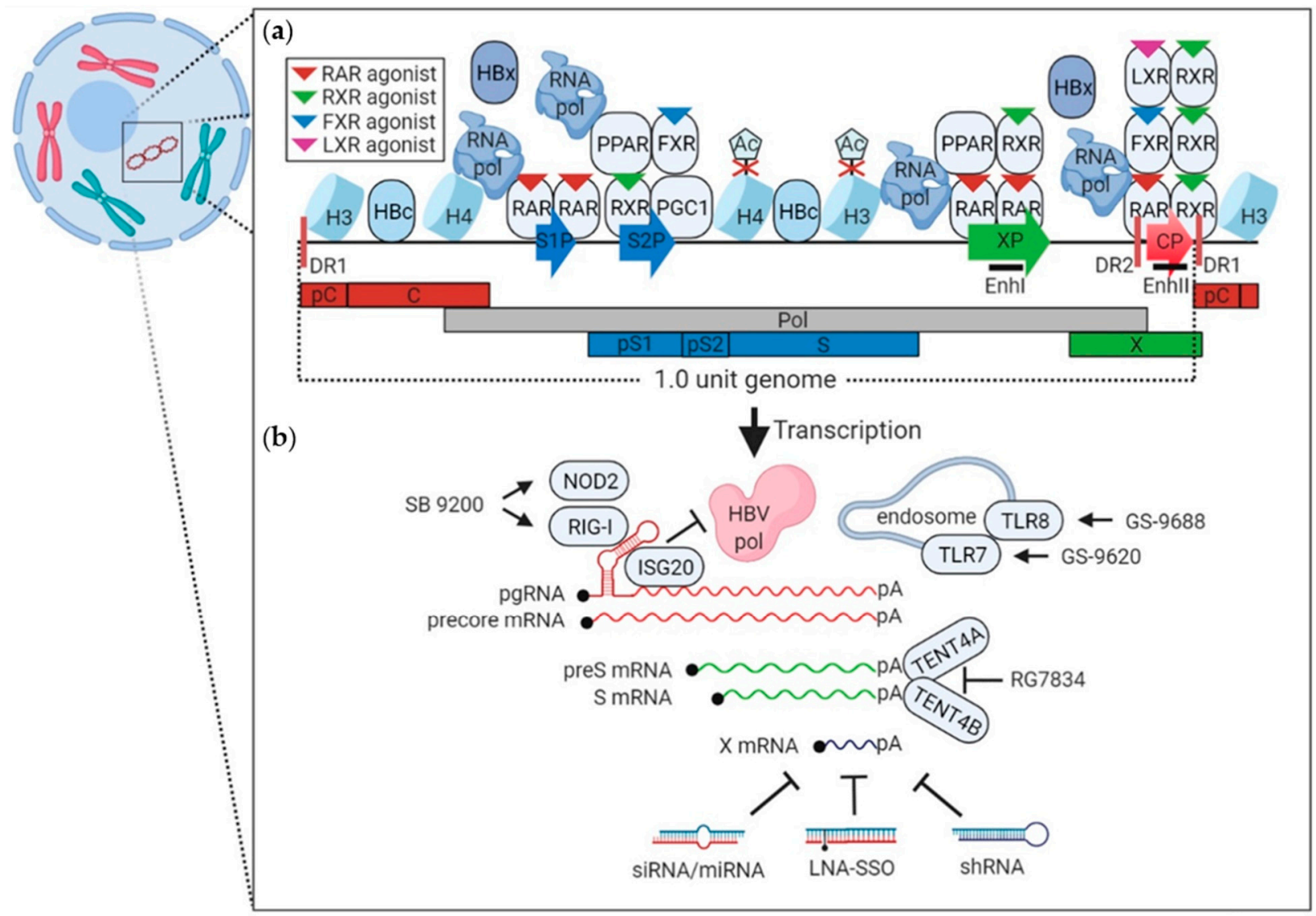

Figure 2. Approaches to inhibit transcription and interfere with viral transcripts. (a) The 1.0 unit genome is packaged with essential host factors, histone $3(\mathrm{H} 3)$ and $4(\mathrm{H} 4)$, RNA polymerase (RNA pol), as well as associated $\mathrm{HBc} A g(\mathrm{HBc})$ and $\mathrm{HBx}$. Agents that block the acetylation of $\mathrm{H} 3$ and $\mathrm{H} 4$ (red cross) repress general transcription. Homodimers (i.e., RAR-RAR) and heterodimers (i.e., RAR-RXR, FXR-RXR, LXR-RXR, etc.) bind specific promoter and enhancer regions and maintain transcription. When RAR, RXR, FXR, and LXR agonists (shown as inverted triangles and summarized in Table 1) bind these nuclear receptors, transcription from the HBV promoter is suppressed. Core (CP), preS (S1P), S (S2P), and X promoters (XP) are shown as arrows overlaid onto the 1.0 unit HBV genome. Each promoter controls the transcription of core (pC-C, shown in red), polymerase (Pol, in gray), S (pS1-pS2-S, in blue), and X (in green) open reading frames, respectively. Two enhancers (EnhI and EnhII, thick black line) are marked along with direct repeat elements (DR1 and DR2, thick red line). (b) TLR7 (i.e., GS-9620) and TLR8 agonists (i.e., GS-9688) induce endosome-mediated sensing of single-stranded viral transcripts. Targeting pgRNA (red), ISG20 prevents HBV polymerase (pol) binding to the pgRNA, while RIG-I/NOD2 agonists (i.e., SB 9200) promote RIG-I specific binding to the $\varepsilon$ region in the pgRNA, which competes for polymerase-pgRNA association and subsequent virion encapsidation. PreS and S mRNAs (green) are stabilized by host enzymes TENT4A/B (PAPD5/7), which can be inactivated by a specific inhibitor, RG7834. In addition to small molecules, RNA interference mediates the degradation of all HBV transcripts including X mRNA. Locked nucleic acids (LNA-SSO), small hairpin RNA (shRNA), small interfering RNA (siRNA), as well as microRNA (miRNA) have been developed to bind viral transcripts, mediating their decay.

HBV encodes HBx as a viral transactivator and uses this to promote transcription from cccDNA. Expressed early post infection, HBx does not directly bind cccDNA but is recruited onto the minichromosome and modulates the stability of acetylated histones. In the case of HBx-minus HBV mutants, histones are hypoacetylated, while the recruitment of histone deacetylases histone deacetylase 1 (HDAC1) and sirtuin-1 (SIRT1) are profoundly increased [73]. Furthermore, mapping analysis determined that C-terminally mutated HBx recruits less acetyltransferase p300 and more HDAC1 onto cccDNA templates [95]. HBx not only initiates but also maintains transcription from cccDNA. Lentiviral trans-complementation of $\mathrm{HBx}$ rescued active transcription from the HBx-minus virus 
for weeks post infection, confirming that $\mathrm{HBx}$ but not other viral proteins promote viral transcription [96]. In parallel, HBx physically binds DNA damage-binding protein 1 (DDB1) [97]. This complex further hijacks Cullin 4, which is a component of host E3 ubiquitin ligases, and mediates ubiquitin-proteasomal degradation of host restriction factor structural maintenance of chromosome 5/6 (SMC5/6) on the cccDNA $[98,99]$. However, how SMC5/6 blocks transcription from cccDNA remains unclear. SMC5/6 may recognize an HBV-specific sequence motif, but this seems unlikely, as HBx-mediated augmentation of gene transcription is limited to extrachromosomal DNA templates: this phenomenon is not observed for HBV genomes with identical sequences integrated into host chromosomes [100]. Another possibility is that SMC5/6 senses the supercoiled cccDNA at transcription initiation and topologically fixes cccDNA in the supercoiled state, at which point transcription elongation is not possible. Although SMC5/6 shapes the topology of normal chromosomes, it plays no obvious role in the transcription of cellular genes.

Current knowledge of gene transcription from HBV genomic integrants remains limited. HBV integrants are randomly distributed throughout the entire host genome, without any evidence for preferential integration sites or adjacency to specific gene classes. The transcription from integrants is independent and not associated with cccDNA-mediated viral replication, since there is no difference in HBeAg positive and negative patients [101,102]. Indeed, preS/S transcripts generated from integrants but not episomes become dominant in HBeAg-negative chimpanzees [103]. Similar to episomal cccDNA, the transcription process also is driven by preS/S promoters and regulated by HBV enhancers. However, depending on how close the integration site is to cellular enhancers or repressors, transcription efficiency may differ between individual integrants. Some integrants transcribe a C-terminally truncated HBx viral-cell fusion gene (i.e., HBx-LINE). Despite the lack of its C-terminus, the HBx in the fusion still retains transactivation activity [104,105], because deletion of the C-terminal 14 amino acids (residues 141-154) does not abolish that function [106]. Furthermore, random insertion of the foreign HBV genome into host genomes may result in genomic instability and transcriptional perturbations affecting multiple genes $[107,108]$. The function of affected genes can determine progression to carcinogenesis [109].

Table 1. Inhibitors targeting HBV transcription.

\begin{tabular}{|c|c|c|c|c|c|c|}
\hline Substance & Property & Target & Clinical Status & $\begin{array}{c}\text { IC }_{50} \mathrm{HBV} \\
\text { Transcription }\end{array}$ & Inventor & Reference \\
\hline IFN- $\alpha$ & Cytokine & STAT1/2,histones & Approved & $\begin{array}{l}180 \mu \mathrm{g} / \text { week } \\
1_{500 \mathrm{IU} / \mathrm{mL}}\end{array}$ & Merck $^{2}$ & {$[110,111]$} \\
\hline rIL-6 & Cytokine & STAT3,HNF1 $\alpha / 4 \alpha$ & Preclinical & $20 \mathrm{ng} / \mathrm{mL}$ & $\mathrm{n} / \mathrm{a}$ & {$[112,113]$} \\
\hline TGF- $\beta$ & Cytokine & $\mathrm{HNF} 4 \alpha, \mathrm{AID}$ & Preclinical & $10 \mathrm{ng} / \mathrm{mL}$ & $\mathrm{n} / \mathrm{a}$ & [114-116] \\
\hline Tazarotene(Tazorac) & Small molecule & $\operatorname{RAR} \beta / \gamma$ & Approved $^{3}$ & $20-75 \mathrm{nM}$ & Allergan & [117] \\
\hline Tamibarotene(Am80) & Small molecule & $\operatorname{RAR} \alpha$ & Approved ${ }^{3}$ & $\approx 1 \mathrm{nM}$ & Nippon Shinyaku & [118] \\
\hline Isotretinoin(Accutane) & Small molecule & RAR/RXR & Approved ${ }^{3}$ & $1.2 \mu \mathrm{M}$ & Roche & [119] \\
\hline Bexarotene(Targretin) & Small molecule & $\mathrm{RXR} \alpha$ & Approved 3 & $1-5 \mu \mathrm{M}$ & Ligand Pharma & [120] \\
\hline GW4064 & Small molecule & $\mathrm{FXR} \alpha$ & Preclinical & $0.2 \mu \mathrm{M}$ & GSK & {$[121,122]$} \\
\hline EYP001 & Small molecule & FXR & Phase II & $1.25-2.5 \mu \mathrm{M}$ & Enyo Pharma & [123] \\
\hline T0901317 & Small molecule & $\mathrm{LXR} \alpha / \beta$ & Preclinical & $0.3-3 \mu \mathrm{M}$ & Merck & [124] \\
\hline GW3965 & Small molecule & $\mathrm{LXR} \alpha / \beta$ & Preclinical & $0.3-3 \mu \mathrm{M}$ & GSK & {$[124]$} \\
\hline MLN4924 & Small molecule & NAE1 & Phase II/III ${ }^{3}$ & $290 \mathrm{nM}$ & Takeda & [125-127] \\
\hline Nitazoxanide & Small molecule & HBx-DDB1 & Approved ${ }^{3}$ & $20 \mu \mathrm{M}$ & Romark Lab. & {$[128,129]$} \\
\hline
\end{tabular}

${ }^{1}$ Dose for patients according to the AASLD guideline in $2016 .{ }^{2}$ Referring to in particular Intron A (IFN- $\alpha$-2b). ${ }^{3}$ Approved for administrations other than chronic HBV infection. $\mathrm{IC}_{50}$ : half maximal inhibitory concentration in in vitro models; IFN: interferon; IL: interleukin; STAT: signal transducer and activator of transcription; TGF: tumor growth factor; HNF: hepatic nuclear factor; AID: activationinduced cytidine deaminase; RAR: retinoic acid receptor; RXR: retinoid X receptor; FXR: farnesoid X receptor; LXR: liver X receptor; NAE1: NEDD8-activating enzyme 1; DDB1: DNA-damage binding protein 1. GSK: GlaxoSmithKline. n/a: not applicable. 


\section{Strategies Targeting Viral Transcription \\ 6.1. Cytokines}

An approved antiviral therapeutic, IFN- $\alpha$ does not directly inhibit viral replication but stimulates the induction of interferon-stimulated genes (ISGs), the protein products of which possess broad antiviral activity. Targeting multiple steps in the HBV life cycle, ISGs exert a range of distinct mechanisms to control HBV replication [130]. IFN- $\alpha$ treatment induces STAT1/2 recruitment onto cccDNA that represses transcription. In addition, the cytokine inhibits transcription from cccDNA by modulating its epigenetic modification both in vitro and in humanized mice. IFN- $\alpha$ leads to histone hypoacetylation at the H3K9 and H3K27 residues and recruitment of transcriptional repressors such as HDAC1 onto the cccDNA (Table 1) $[110,111]$. One of the ISGs, apolipoprotein B mRNA editing enzyme catalytic subunit 3A (APOBEC3A), binds HBcAg to facilitate attachment to cccDNA [131]. Deaminated ccCDNA via APOBEC3A is prone to degradation by the hydrolysis of nuclease ISG20 (Stadler et al., in press). Moreover, IFN-induced tripartite motif 22 protein (TRIM22) inhibits core promoter activity and viral gene expression both in vitro and in vivo [132].

Pro-inflammatory interleukin-6 (IL-6) inhibits pgRNA and preS/S transcription from cccDNA in infected HepG2 ${ }^{\text {NTCP }}$ cells. Recombinant IL-6 (rIL-6) treatment dissociates HNF1 $\alpha$ and HNF4 $\alpha$ with cccDNA, both of which are required for transcription as described above. rIL-6 induces the overall phosphorylation of STAT3; however, lower levels of phospho-STAT3 are recruited onto the cccDNA compared to IL-6 cellular target genes. This redistribution results in decreased HBV transcription [112].

Transforming growth factor (TGF- $\beta$ ) treatment induces the expression of activationinduced cytidine deaminase (AID), and to a lesser extent, APOBEC3F and 3G but not APOBEC3A. AID associates with HBV RNA and can be incorporated into nucleocapsids, where viral pgRNA gets deaminated [114]. AID-mediated HBV reduction takes place in a polymerase-dependent manner, which requires a physical association between AID and the polymerase. This interaction further mediates a recruitment of RNA exosome proteins [115]. Similar to IFN- $\alpha$ and IL-6, TGF- $\beta$ also significantly downregulates HNF4 $\alpha$ expression and core promoter activity, which leads to a reduction in the amount of pgRNA [116]. These findings identify HNF (especial HNF4 $\alpha$ ) as an attractive drug target. Agents blocking HNF activity or dissociating it from cccDNA would potentially inhibit viral gene transcription from cccDNA.

\subsection{Retinoic Acid Receptor Agonists}

Efficient transcription from cccDNA relies heavily on NRs that bind to response elements in the promoters or enhancer regions in a sequence-dependent manner [133]. For instance, the retinoic acid receptor (RAR) homodimers and heterodimers recognize the DNA element $5^{\prime}-(\mathrm{A} / \mathrm{G}) \mathrm{G}(\mathrm{G} / \mathrm{T}) \mathrm{TCA}-3^{\prime}$ located in the core, preS, and X promoters (Figure 2a). If a ligand binds the receptor, transcription from these promoters is repressed. Likewise, small-molecule RAR agonists also exert transcriptional inhibition.

Tretinoin (all-trans retinoic acid), Acitretin, Adapalene and Tazarotene were identified by screening a library of FDA approved drugs. The most potent hit, Tazarotene, inhibits transcription from cccDNA with $\mathrm{IC}_{50}$ values of $20-75 \mathrm{nM}$ without reducing cccDNA levels. It targets mostly RAR $\beta$ but not RAR $\alpha$ and RAR $\gamma$ in infected primary hepatocytes [117]. Nkongolo et al. identified Tamibarotene (Am80) using another FDA-approved drug library and further compared Tamibarotene (RAR $\alpha$-specific) with other agonists: Tazarotene (RAR $\beta$-specific), Adapalene (RAR $\gamma$-specific), and all-trans retinoic acid (pan-activity). Remarkably, Tamibarotene inhibits transcription selectively from cccDNA in primary hepatocytes but shows no effect on the transcription from integrants in HepG2.2.15 cells [118]. These studies suggested that RAR agonists targeting one subunit in the dimer would be sufficient to shut down gene transcription from cccDNA. Of note, RAR also modulates NTCP promoter activity. RAR $\alpha$ stimulation by Ro41-5253 prevents NTCP expression and diminishes hepatocyte permissiveness to HBV infection [134]. 
RAR agonists have shown promising in vitro activity. However, Birkus et al. compared twenty RAR agonists in vitro and selected Accutane for in vivo experiments using PXB humanized mice that were treated twice per day with $30 \mathrm{mg} / \mathrm{kg}$ Accutane for 28 days. Neither HBV DNA nor HBsAg levels were reduced by Accutane in vivo [119]. In a parallel study, we treated uPA-SCID humanized mice with $1 \mathrm{mg} / \mathrm{kg}$ Tamibarotene daily for 14 days (in vitro $\mathrm{IC}_{50}$ value: $1 \mathrm{nM}$ ). In agreement with Birkus et al., HBV DNA and HBsAg levels were not altered (data not shown). It is unclear whether these agonists administered at tolerable doses induce effective RAR responses in the liver.

\subsection{Retinoid X Receptor Agonists}

Associated with peroxisome proliferator-activated receptor (PPAR) or farnesoid X receptor $(F X R)$, retinoid $X$ receptor $(R X R \alpha)$ heterodimers bind enhancers I and II at putative DNA elements 5'-TGAACCTTTACCC- $3^{\prime}$ and 5'-CTGAACCTTTACCC- ${ }^{\prime}$, respectively $[135,136]$. RXR-specific agonist Bexarotene inhibits the transcription of pgRNA and other viral RNAs in HepG2 ${ }^{\mathrm{NTCP}}\left(\mathrm{IC}_{50}\right.$ value: $\left.1-5 \mu \mathrm{M}\right)$, HepaRG $(\approx 5 \mu \mathrm{M})$, and primary tree shrew hepatocytes $(\approx 5 \mu \mathrm{M})$. Moreover, transient or stable silencing of $\mathrm{RXR} \alpha$ expression enhances HBV replication. RXR $\alpha$ disruption is accompanied by the genetic downregulation of arachidonic acid and eicosanoid pathways, which is responsible for hepatic lipid metabolism [120]. The contribution of these metabolic pathways to the efficacy of Bexarotene's antiviral effect requires further characterization.

\subsection{Farnesoid X Receptor Agonists}

FXR $\alpha$ is a nuclear receptor activated by its natural ligand, bile acids $[137,138]$. It interacts with PPAR or RXR $\alpha$ to form heterodimers. The dimer binds to a particular DNA response element 5'-AGGTCANTGACCT-3' located at enhancer II and S promoter and thereby transactivates several genes involved in hepatic lipid and bile acid metabolism $[139,140]$. It is worth noting that bile acids activate the FXR-RXR heterodimer that transcribes Src homology region 2 domain-containing phosphatase-1 (SHP-1). SHP-1 can inactivate the RAR-RXR heterodimer and prevent the expression of NTCP. Due to negative feedback, down-regulated NTCP in turn lowers the influx transport of bile acids [141]. Therefore, both FXR-RXR and RAR-RXR receptors might play essential roles in bile acid metabolism and HBV replication.

FXR agonist GW4064 and a bile salt derivative 6ECDCA inhibit the expression of viral mRNA, with an $\mathrm{IC}_{50}$ value of $0.2 \mu \mathrm{M}$, and reduce cccDNA levels in differentiated HepaRG cells. GW4064 treatment reverses most of the HBV-upregulated FXR gene expression [121]. Further investigation has demonstrated that GW4064 treatment affects cccDNA levels for both wild-type and HBx-minus viruses, which was consistent with the concept that $\mathrm{HBx}$ is not involved in cccDNA formation and maintenance. However, GW4064-induced inhibition of pgRNA and precore mRNA transcription is HBx dependent [122]. These data imply that HBx likely interacts with FXR heterodimers in the minichromosome. Another agonist, EYP001, has been validated in preclinical and phase I trials. The drug was well tolerated in healthy volunteers, reduced HBV DNA and HBsAg levels in HepaRG cells, and showed an additional effect on HBV DNA in combination with Entecavir [123].

\subsection{Liver X Receptor Agonists}

Liver $X$ receptor $(\mathrm{LXR})$ is a pivotal regulator in lipid and cholesterol metabolism, with at least two subtypes, $\mathrm{LXR} \alpha$ and $\mathrm{LXR} \beta$, both of which interact with RXR. The heterodimer binds specific DNA element 5'-AGGTCANNNNAGGTCA-3' and regulates the transcription of multiple genes [142]. Recently, LXR agonists have been tested for anti-HBV activity. Two agonists T0901317 and GW3965 but not antagonist SR9238 potently inhibited the gene expression and transcription of viral RNAs in HepaRG and primary hepatocytes, although cccDNA levels were not substantially reduced. Remarkably, no significant antiviral activity was observed in HepG2 ${ }^{\text {NTCP }}$ cells [124]. These data suggest that the metabolic profile in HepG2 hepatoma cells might be distinctly different from that in primary hepatocytes. Both 
agonist treatments decrease cholesterol $7 \alpha$ hydroxylase 1 (CYP7A1) mRNA levels. Silencing CYP7A1 inhibits HBV replication in primary hepatocytes, illustrating that CYP7A1 is a host dependency factor associated with the LXR pathway.

\subsection{Inhibitors Acting on the HBx-DDB1 Complex}

Two independent studies have demonstrated that HBx, as the sole HBV-encoded transactivator, can be targeted by small molecules. Qu et al. reported that MLN4924 (Pevonedistat) inhibits HBV replication with $\mathrm{IC}_{50}$ values as low as $62 \mathrm{nM}$ and further characterized it as a transcriptional inhibitor of genotype D HBV-infected HepG2 ${ }^{\mathrm{NTCP}}$, HepaRG $^{\text {NTCP }}$ cells, and primary hepatocytes. Notably, MLN4924 selectively reduces the enhanced transcription by lentiviral HBx expression at the baseline level of that of $\mathrm{HBx}-$ minus virus, suggesting a dependency on $\operatorname{HBx}[125,126]$. Meanwhile, Sekiba et al. found that MLN4924 restores SMC5/6 protein expression and reduces viral transcription in the HBV minicircle system and in primary hepatocytes infected with genotype C HBV [127]. These side-by-side studies identify MLN4924 as a promising transcriptional inhibitor.

Nitazoxanide, as well as its metabolite tizoxanide, has a broad antiviral activity toward HBV and HCV [143]. Using a split luciferase system that allows a screening of agents interfering with HBx-DDB1 association, Sekiba et al. identified Nitazoxanide in an FDA-approved drug library. The drug inhibits viral RNA transcription in HepG2 cells transfected with HBV minicircles and HepAD38 cells with integrants. However, Nitazoxanide suppresses viral transcription in primary hepatocytes infected with genotype $C \mathrm{HBV}$ only at a very high dose $(20 \mu \mathrm{M})$ [128]. Such an in vitro dose will limit further clinical development. Furthermore, Nitazoxanide at high doses was unable to completely block HBx-DDB1 binding, although the binding was reduced as shown by a co-immunoprecipitation assay. These disadvantages indicate that Nitazoxanide is not a viable candidate for further clinical development.

\section{Strategies to Degrade Existing Transcripts}

\subsection{Interferon Stimulated Genes (ISGs)}

In addition to its function in cccDNA degradation, ribonuclease ISG20 directly binds to the $\varepsilon$ region of viral pgRNA and degrades it in the presence of co-factors (Figure 2b) $[144,145]$. Further study characterized that the N6 methyladenosine modified viral transcripts are selectively sensed by ISG20 and processed for degradation [146]. IFN $\alpha$-induced zinc finger proteins trigger viral RNA decay in vitro and in a transgenic mouse model $[147,148]$. One adaptor protein in the Toll-like receptor pathway, myeloid differentiation primary response protein 88 (MyD88), facilitates the decay process [149]. IFN $\alpha$ inducible myxoma resistance protein 1 (MxA) impedes pgRNA encapsidation by interacting with HBcAg $[150,151]$.

\subsection{Terminal Nucleotidyltransferase}

Terminal nucleotidyltransferase 4A (TENT4A) and 4B (TENT4B) proteins (also termed PAPD7 and PAPD5) are non-canonical poly(A) RNA polymerases that generate "mixed tails" of various nucleotides at the $3^{\prime}$ termini of RNAs by means of non-templated addition to protect mRNA from deadenylation. HBV hijacks this machinery via exploiting the TENT-ZCCHC14 complex and creates mixed tailing for protection as characterized by TAIL-seq [152]. HBV gene expression is severely impaired, when TENT4A and TENT4B are simultaneously knocked down. In particular, knockdown of the TENTs results in the destabilization and degradation of HBV mRNAs without affecting the production of viral pgRNA transcripts [153]. RG7834, belonging to the dihydroquinolozinone chemical family, was identified to target catalytic domains of both TENTs. RG7834 has an $\mathrm{IC}_{50}$ value of 2-6 nM in vitro and shows a selective reduction in HBV mRNAs and HBsAg. In addition, RG7834 given orally to humanized mice leads to a mean 1.09 log-scale HBsAg reduction compared to Entecavir treatment (Table 2) [154]. In line with this finding, Hyrina et al. identified that ZCCHC14 together with TENTs stabilize HBsAg expression via $3^{\prime}$ RNA tailing, but so far, no inhibitor targeting ZCCHC14 is available [155]. 
Table 2. Inhibitors targeting and silencing HBV transcripts.

\begin{tabular}{|c|c|c|c|c|c|c|}
\hline Substance & Property & Target & Clinical Status & Effective Dose & Inventor & Reference \\
\hline RG7834(Ro7020322) & Small molecule & TENT4A/B & Phase I & $2-6 \mathrm{nM}$ & Roche & {$[153,154]$} \\
\hline DHQ-1 & Small molecule & Unclear & Preclinical & $100 \mathrm{nM}$ & Blumberg Institute & [156] \\
\hline GS-9620(Vesatolimod) & Small molecule & TLR7 & Phase II & -3 & Gilead & [157-159] \\
\hline RG7854 & Small molecule & TLR7/8 & Phase I & $\mathrm{n} / \mathrm{a}$ & Roche & Undisclosed \\
\hline SB 9200(Iranigivir) & Small molecule & RIG-I and NOD2 & Phase II & $30 \mathrm{mg} / \mathrm{kg} 4$ & Spring Bank Pharma & [163] \\
\hline $\mathrm{AB}-452$ & Undisclosed & HBV RNA & Phase I ${ }^{1}$ & $\mathrm{n} / \mathrm{a}$ & Arbutus Biopharm. & [164] \\
\hline HBVU6no.2 & shRNA & HBV S region & Preclinical & $<5 \mu g^{5}$ & $\mathrm{n} / \mathrm{a}$ & [165] \\
\hline ALN-HBV(ALN-HBV01) & GalNAc-siRNA & $\mathrm{n} / \mathrm{a}$ & Phase I ${ }^{2}$ & $\mathrm{n} / \mathrm{a}$ & Alnylam Pharma & [168] \\
\hline ARC $-520^{\S}$ & GalNAc-Chol-siRNA & HBV X region & Phase II ${ }^{2}$ & $<1 \mathrm{mg} / \mathrm{kg}^{7}$ & Arrowhead Pharma & {$[169,170]$} \\
\hline ARB-1467(TKM HBV) & siRNA & $\mathrm{S}$ and $\mathrm{X}$ regions & Phase II & $0.4 \mathrm{mg} / \mathrm{kg}^{8}$ & Arbutus Biopharma & [171] \\
\hline VIR-2218(ALN-HBV02) & GalNAc-siRNA & HBV $X$ region & Phase I/II & $\mathrm{n} / \mathrm{a}$ & Alnylam and VIR & EASL 2020 \\
\hline JNJ-3989(ARO-HBV) & siRNA pool & $\mathrm{S}$ and $\mathrm{X}$ regions & Phase II & $<400 \mathrm{mg} / \mathrm{month}$ & Arrowhead and Janssen & [172] \\
\hline AB-729 & GalNAc-siRNA & HBV RNA & Phase I & $6 \mathrm{nM}$ & Arbutus Biopharma & [173] \\
\hline RG6346(DCR-HBVS) & GalXc-siRNA & $\mathrm{n} / \mathrm{a}$ & Phase I/II & $\mathrm{n} / \mathrm{a}$ & Dicerna Pharma and Roche & AASLD 2020 \\
\hline GSK3228836 (IONIS-HBVRx) & Antisense oligonucleotide & HBV $X$ region & Phase II & $\mathrm{n} / \mathrm{a}$ & IONIS Pharma and GSK & EASL 2020 \\
\hline GSK3389404 (IONIS-HBVLRx) & Antisense oligonucleotide & $\mathrm{HBV} X$ region & Phase II & $\mathrm{n} / \mathrm{a}$ & IONIS Pharma and GSK & [174] \\
\hline Ro7062931(LNA-SSO) & GalNAc-Oligonucleotide & HBV X region & Phase I & $\approx 1 \mu \mathrm{M}$ & Roche & [168] \\
\hline Lunar-HBV & UNA oligomer & $\mathrm{S}$ and $\mathrm{X}$ regions & Preclinical & $\mathrm{n} / \mathrm{a}$ & Arcturus and Janssen & AASLD 2016 \\
\hline miR-122 mimic & microRNA & HBV RNA & Preclinical & $40 \mathrm{nM}$ & $\mathrm{n} / \mathrm{a}$ & {$[176,177]$} \\
\hline
\end{tabular}

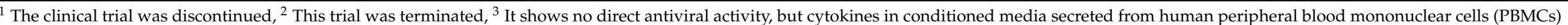

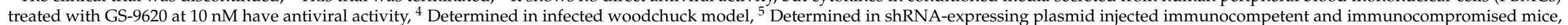

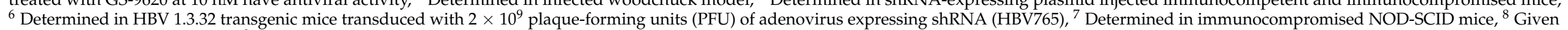

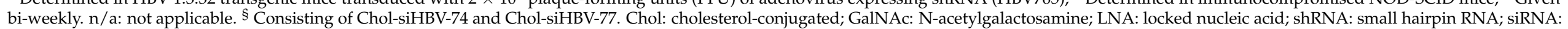

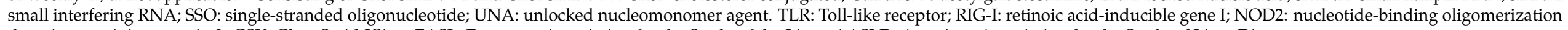
domain-containing protein 2. GSK: GlaxoSmithKline. EASL: European Association for the Study of the Liver. AASLD: American Association for the Study of Liver Diseases. 


\subsection{Innate Immune Agonists}

As one of the pathogen-associated molecular patterns, foreign RNA can be recognized by innate immune sensors, including TLR7/8 (specific for ssRNA), TLR3 (for dsRNA), RIGI (for 5' triphosphate RNA), and MDA5 (for long dsRNA) and so on [178]. TLR7 agonist GS-9620 has been extensively studied. GS-9620 shows marked and sustained reduction in viral load in woodchucks chronically infected with WHV and chimpanzees infected with HBV $[179,180]$. Surprisingly, no significant clinical changes in viral DNA and HBsAg levels were observed in CHB patients in phase $\mathrm{Ib} / \mathrm{IIa}$ trials [181,182]. Without a direct antiviral activity, GS-9620 can induce IFN- $\alpha$, other cytokines, as well as intrahepatic T-cell and B-cell aggregates $[157,158]$. Although they enhance HBV antigen presentation, overall immune responses are likely not sufficient to counteract HBV replication in patients. Treatment with media from PBMCs stimulated with TLR8 agonist GS-9688 shows a reduction in viral markers in primary hepatocytes. In woodchucks, treatment reduces intrahepatic WHV DNA and RNA levels by 20 -fold $[183,184]$. A pan-TLR7/8 agonist, RG7854, is also under evaluation (Table 2).

RIG-I has a dual action against HBV replication. RIG-I senses the $5^{\prime} \varepsilon$ region of viral pgRNA and induces type III interferon production. Through binding the $\varepsilon$ region, RIG-I also competes with the interaction between $\varepsilon$ and viral polymerase, which substantially suppresses polymerase-mediated encapsidation (Figure 2b) [185]. Based on these findings, RIG-I/NOD2 agonist SB 9200 (Iranigivir) was developed and evaluated. SB 9200 treatment lowers serum and hepatic levels of WHV DNA and intrahepatic levels of viral RNA in woodchucks [163].

A major limitation of innate immune agonists is that PBMCs rather than infected hepatocytes exhibited better responses. The agonists elicit IFN- $\alpha$ and ISG production, which eventually modulates hepatocytes via an immune-regulatory mechanism. However, the hepatocytes frequently exposed to a quantity of foreign RNA from digested foods and intestinal microbiota have established a strategy that limits the expression levels of the sensors to avoid excessive innate sensing. Furthermore, the cytokines secreted by PBMCs may lead to unexpected and potentially damaging immune responses in the liver.

\section{4. shRNA and siRNA}

Oligonucleotide-based inhibitors are maturing as therapeutics. The majority of these are either small RNAs mediating their antiviral effect via the RNA-induced silencing complex (RISC) or single-stranded DNA-like molecules recruiting RNase H-mediated mRNA degradation. In one of the first studies examining their efficacy, Huh7 cells or mice were co-transfected or hydrodynamically injected, respectively, with one HBV-expressing plasmid and a second plasmid encoding small hairpin RNA (shRNA) homologous to viral mRNAs [165]. Next, HepG2.2.15, HepAD38, and HepAD79 cell lines carrying stable HBV integrants were transfected with synthesized small interfering RNA (siRNA) [186-188]. One of the candidates, HBVU6no.2, which specifically binds to the $S$ region, led to a reduction of pgRNA and preS/S mRNAs, as confirmed by Northern blotting. Secreted HBsAg was reduced by $94 \%$ in transfected cells and $84 \%$ in mouse serum upon RNAi treatment, while intrahepatic HBcAg was also reduced by $>99 \%$ [165]. Furthermore, another candidate, shHBV765, was evaluated using HBV transgenic mice transduced with recombinant adenovirus encoding these targeting shRNAs. The treatment diminished $\mathrm{preS} / \mathrm{S}$ transcripts and, to lesser extent, pgRNA, on day 26 in mice [167]. These early studies suggested that active transcription, not only from an episomal plasmid but also from viral genomic integrants, could be successfully targeted upon shRNA and siRNA treatments.

A major problem to extend the use of first-generation small RNAs as a therapeutic is the scarcity of effective liver-specific delivery. To solve it, preferential RNA delivery into hepatocytes requires carriers (liposome, nanoparticles, etc.) and conjugates to enter the hepatocytes, to adapt to the cellular environment and to avoid endosomal sequestration [189]. Cholesterol-conjugated siRNAs (chol-siRNA) enable transmembrane delivery into the cytosol via membrane fusion. Chol-siRNA is further modified with a disulfide bond, a car- 
boxy dimethylmaleic anhydride (CDM), and a tri-antennary $\mathrm{N}$-acetylgalactosamine cluster (GalNAc). GalNAc mediates hepatocyte targeting via its binding to the hepatocyte-specific expressed asialoglycoprotein receptor (ASGPR). After ASGPR-mediated endocytosis, the unstable acidic CDM is hydrolyzed in the endosome, destabilizing the endosome. When the disulfide bond is cleaved, the small RNA escapes from the endosome and is released in the cytosol.

Modified chol-siRNAs exhibit more than 500-fold improvement in knockdown efficacy compared to the chol-siRNA alone. Accordingly, Wooddell et al. designed ARC-520, which is composed of two different chol-siRNAs (chol-siHBV-74 and -77) and one CDM-GalNAc labeled peptide $[169,170]$. In these experiments, ARC-520 showed safe and efficient activity in reducing viral RNA levels in mice injected with HBV plasmids, HBV transgenic mice, and cynomolgus monkeys [170]. However, upon ARC-520 treatment, while HBsAg levels were profoundly reduced in treatment-naive $\mathrm{HBeAg}$ positive patients, smaller reductions were observed in patients who had received nucleos(t)ide therapy or were HBeAg negative. Experiments in chimpanzees further suggested that this reduced efficacy is due to transcriptionally active integrants lacking $3^{\prime}$-end target sites for two siRNAs in ARC$520[103,190]$. Using similar strategy, GalNAc-modified siRNA candidates (summarized in Table 2: JNJ-3989, VIR-2218, RG6346, etc.) were designed and evaluated in clinical trials. Data released after the ongoing trials will broaden our understanding of the efficacy and potency of these inhibitors.

\subsection{Single-Stranded Oligonucleotides}

An alternative strategy is to employ single-stranded DNA-like oligonucleotides (SSO), which are typically 12 to 20 mers in length. They bind the mRNA target and mediate its degradation by via RNase $\mathrm{H}$ activity. These oligonucleotides are often modified with locked nucleic acids (LNA), which are nucleotide analogs that contain a methylene bridge between the $4^{\prime}$-carbon and the oxygen atom at $2^{\prime}$-carbon in the ribose ring. This stabilizes the whole structure and improves intracellular stability [191]. In an early study, LNA-modified oligonucleotides were labeled with Alexa546 fluorescein and designed to target pgRNA at the $5^{\prime}$ terminus. By lipofectamine transfection, the LNA-Alexa oligonucleotides showed exclusive nuclear localization and potent inhibition of viral pgRNA at $24 \mathrm{~h}$ post transfection in HepG2.2.15 cells [175]. Furthermore, one antisense oligonucleotide was selected to target the most conserved region among all the HBV genotypes in the $X$ open reading frame. Unmodified oligonucleotides are unstable [192]; however, modified ones are safe, stable, and potent. They have shown dose-dependent inhibitory effects on viral replication from integrants in HepG2.2.15 cells and transgenic mice. Moreover, the treatment also leads to a 10 -fold reduction in transcription from episomal templates, including cccDNA in infected Huh7 $7^{\mathrm{NTCP}}$ cells and 1.3 genomic unit plasmids injected into immunodeficient mice [193]. Recently, Javanbakht et al. engineered LNA-SSO and further conjugated it to three GalNAc moieties to facilitate specific binding to the liver-specific ASGPR. Strikingly, the GalNAc-LNA-SSO has shown remarkably high potency in AAV-HBV transduced mice and resulted in a sustained $>1000$-fold reduction in HBsAg expression [168]. So far, there are two more oligonucleotides available in phase II trial as summarized in Table 2. Since most oligonucleotide-based inhibitor trials have undisclosed data, it is not currently possible to compare their efficiencies.

\subsection{MicroRNAs}

Finally, mature microRNAs (miR) processed from a pre-miR precursor can recruit Ago and Dicer proteins, assemble the RISC complex, and drive the degradation of the mRNA target containing an miR-complementary sequence. It is also possible to transfect an exogenous miR mimic that functions similarly to the authentic miR. MiR-122 is a liver-enriched miR that plays essential roles in the maintenance of HCV RNA replication. MiR-122 binds seed sites present in the $5^{\prime}$-untranslated region and stabilizes HCV genomes [194]. Therapeutic silencing of miR-122 in primates leads to long-lasting sup- 
pression of HCV replication [195]. However, whether miR-122 interacts directly with HBV transcripts remains unclear. It has been reported that miR-122 can inhibit viral pgRNA expression, whereas silencing it leads to increased HBV production. MiR-122 induces downregulation of heme oxygenase-1 (HO-1), and knocking HO-1 down results in an increase in HBV replication. However, whether HO-1 mRNA is an authentic target of miR122 was unclear [176]. Another study demonstrated that HBx interferes with p53 binding to core promoter and enhancer I via miR-122 downregulation; hence, this increases HBV transcription [177]. Unveiling cellular target(s) of miR-122 in infection models will help us to evaluate whether therapeutic use of a miR-122 inhibitor affects HBV gene transcription.

\section{Unanswered Questions}

\subsection{What Is the Next Step for the Development of Nuclear Receptor Agonists?}

Given that many NR agonists have been approved for diseases other than CHB, their safety in humans is already established. However, how to enhance their efficacy and specifically target them toward hepatocytes requires further optimization. As summarized in this review, RAR $\alpha / \beta / \gamma$ and FXR $\alpha$ agonists have the lowest in vitro $\mathrm{IC}_{50}$ values $(<100 \mathrm{nM})$, which suggests that both RAR and FXR heterodimers play essential roles in HBV infection and bile acid metabolism (Table 1) [141]. Despite a potent in vitro effect, in vivo experiments have shown that Accutane was unable to reduce HBV DNA and HBsAg levels in PXB mice repopulated with human hepatocytes and treated daily with $60 \mathrm{mg} / \mathrm{kg}$ for 28 days. Surprisingly, RNA-seq analysis revealed that Accutane treatment leads to different transcriptome profiles in fresh primary human hepatocytes versus those that were transplanted into PXB mice after 28 days [119]. These data suggest that mouse liver environment likely reshapes the metabolic profile of human hepatocytes and makes them insensitive to RAR agonists. Furthermore, these data indicate that liver metabolic systems may exhibit species specificity, and therefore, humanized mice might not represent the most suitable model for the evaluation of NR agonists. In line with this, Brown et al. recently developed a genetic modified mouse model that provides a more human-like metabolic profile in the murine liver, facilitating improved replication of HCV. The ablation of $\mathrm{mCd} 302$ in humanized murine hepatocytes modulates the transcriptional landscape, influencing the expression of multiple components involved in NR signaling [196]. Therefore, this model system may also have potential for development as an HBV drug-screening platform.

\subsection{Does Preventing HBx-Dependent Transcription from cccDNA Lead to a Complete Repression?}

So far, neither MLN4924 nor Nitazoxanide was extensively evaluated in vivo. The sole pilot clinical trial of Nitazoxanide showed that viral loads became undetectable in eight of nine participants and HBsAg seroconversion occurred in three of nine participants as early as 8 weeks upon treatment [129]. Future trials should focus on a larger patient cohort and include all necessary control arms. To achieve a complete repression, blocking HBsAg production from viral transcripts arising from both cccDNA and integrants is required; however, the latter is not controlled by HBx protein. Transcription from viral genome integrations is not sensitive to MLN4924 treatment (Qu and Nebioglu et al., manuscript in submission). Of note, the transcriptional activity of HBx-minus virus is 50-100 fold reduced compared to wild-type virus. If HBx-mediated cccDNA transcription is completely suppressed by MLN4924 and Nitazoxanide, the virus would stay in a "low transcriptional status". Both treatments target the HBx-host factor complex but do not directly degrade HBx [96]. Although targeting HBx cannot lead to a complete repression, candidates that show potency directly against $\mathrm{HBx}$ could be clinically viable and act as "add-on" treatments in combination to nucleos(t)ide analogs and other therapeutics.

8.3. Are Differences between $m R N A$ from cccDNA, $m R N A$ from Integrants, and Cellular $m R N A$ Transcripts Relevant?

The selective effect of TENT4A/B upon RG7834 treatment may be dependent on the differences between cellular and HBV RNA at their $3^{\prime}$-termini. Cellular mRNAs often 
contain two polyadenylation sequences (AAUAAA and AUUAAA) and generate canonical poly(A) tails [197], whereas HBV poly(A) signals contain the sequence UAUAAA, which promotes inefficient polyadenylation [198]. Therefore, TENT4A/B read HBV mRNA as aberrant RNA and further polyadenylate it, allowing selective HBV mRNA processing [199]. It holds true that viral mRNAs containing this UAUAAA tail are usually transcribed from an active cccDNA. Unlike the UAUAAA signal located close to the $5^{\prime}$ region in the dsIDNA, a non-canonical signal CAUAAA located downstream of the HBs reading frame facilitates the polyadenylation of integrant-derived mRNAs [200]. Although both mRNAs from cccDNA and integrants are translated into identical HBsAg, transcripts from these two distinct templates may have minor difference at their $3^{\prime}$ ends. Therefore, using RNA precipitation and sequencing techniques should be possible to determine what types of viral mRNA TENT4A/B bind exactly and dissect the modes of RG7834 and other inhibitors.

\subsection{Can RNAi Strategies Achieve Sustained HBsAg Clearance?}

There are many advantages to targeting of HBV viral transcripts. First of all, all the transcripts derived from both cccDNA or integrants share a common $3^{\prime}$ fragment (Figure 1). Hence, it is practical to design one oligonucleotide that eliminates the translation of proteins from both templates, which has broader efficacy than single protein-targeted inhibitors. Secondly, HBV has a lower mutation rate than either HCV or HIV. Thus, a pool of two and three oligonucleotides targeting highly conserved regions functions as pan-genotypic therapeutic (Table 2). Thirdly, employing GalNAc conjugation and LNA modification, second-generation small RNAs and SSOs show some hepatocyte-specific delivery and minimal off-target effects in other tissues, where HBV transcription does not occur.

RNAi treatment induced a rapid decline in HBsAg expression, which is an indicator of viral transcription, at least according to interim reports. When the current batch of phase II trials are completed, whether these strategies achieve sustained HBsAg clearance will be determined. Furthermore, whether a rebound of viral transcription takes place will also be determined after the follow-up period. Patients with HBsAg reduced beyond a certain threshold upon RNAi treatment may develop efficient HBsAg-specific T-cell responses and have a higher chance of HBsAg seroconversion. Upon nucleos(t)ide analogue treatment, if HBsAg levels are reduced to $<200 \mathrm{IU} / \mathrm{mL}$ at the end of treatment, the patient has lower chances of HBV relapse after cessation of treatment, when HBV DNA has been suppressed [201].

\section{Conclusions}

Current perspectives on HBV RNA synthesis suggest that viral transcription could represent a potential antiviral target $[80,202]$, but a systemic review containing all the concepts of existing and ongoing therapeutics in trial that inhibit transcription and impact on the stability of HBV transcripts was not previously available. In this review, we introduce cutting edge knowledge about both cccDNA and integrant templates responsible for viral transcription, list viral and host factors involved in transcription, and summarize all the druggable candidates into two subsets: the ones targeting the synthesis of viral transcripts and the ones decomposing existing transcripts.

To date, NR agonists have shown potent effects in in vitro infection models. Although the RAR agonist Accutane showed no effects on HBV DNA and HBsAg levels in PXB humanized mice, future experiments should focus on other alternative models with more physiological metabolic profiles, comparable to that observed in primary human hepatocytes. Particular attention should be paid to the results of FXR agonist EYP001, when the phase II trial is completed. A number of GalNAc-conjugated siRNA and LNA-SSOs are also being characterized in phase I/II trials. Whether they give rise to rapid and sustained declines in HBsAg levels in patients is currently under investigation.

In summary, although therapeutic targeting of both HBV cccDNA and genomic integrants is challenging, their transcripts share common features, which represent a conserved point of attack. New strategies aimed at inhibition on HBV RNA synthesis could 
eventually lead to a reduction and some even loss of HBsAg that is difficult to achieve under current therapies for CHB patients. These treatments given alone or as part of combination therapies with nucleos $(\mathrm{t})$ ide analogues may play a role toward a "functional cure" for CHB.

Author Contributions: B.Q. conceptualized this review; B.Q. and R.J.P.B. reviewed the literature; B.Q. drafted the first versions of manuscript; B.Q. prepared all the figures and tables; R.J.P.B. reviewed, edited, and finalized the writing. Both authors have read and agreed to the published version of the manuscript.

Funding: R.J.P.B. was supported by BMG grants 1-2516-FSB-416 and CHARIS 6a.

Institutional Review Board Statement: Not applicable.

Informed Consent Statement: Not applicable.

Acknowledgments: We acknowledge Guofeng Cheng (Ausper Biopharma) for critical reading. We thank Xue Li (University Hospital Heidelberg) for proofreading.

Conflicts of Interest: The authors have no conflicts of interest.

\section{References}

1. Stanaway, J.D.; Flaxman, A.D.; Naghavi, M.; Fitzmaurice, C.; Vos, T.; Abubakar, I.; Abu-Raddad, L.J.; Assadi, R.; Bhala, N.; Cowie, B.; et al. The global burden of viral hepatitis from 1990 to 2013: Findings from the Global Burden of Disease Study 2013. Lancet 2016, 388, 1081-1088. [CrossRef]

2. Lanini, S.; Ustianowski, A.; Pisapia, R.; Zumla, A.; Ippolito, G. Viral Hepatitis: Etiology, Epidemiology, Transmission, Diagnostics, Treatment, and Prevention. Infect. Dis Clin. N. Am. 2019, 33, 1045-1062. [CrossRef]

3. Bartosch, B. Hepatitis B and C viruses and hepatocellular carcinoma. Viruses 2010, 2, 1504-1509. [CrossRef]

4. Vescovo, T.; Refolo, G.; Vitagliano, G.; Fimia, G.M.; Piacentini, M. Molecular mechanisms of hepatitis C virus-induced hepatocellular carcinoma. Clin. Microbiol. Infect. 2016, 22, 853-861. [CrossRef] [PubMed]

5. Lutwick, L.I.; Robinson, W.S. DNA synthesized in the hepatitis B Dane particle DNA polymerase reaction. J. Virol. 1977, 21, 96-104. [CrossRef] [PubMed]

6. Staprans, S.; Loeb, D.D.; Ganem, D. Mutations affecting hepadnavirus plus-strand DNA synthesis dissociate primer cleavage from translocation and reveal the origin of linear viral DNA. J. Virol. 1991, 65, 1255-1262. [CrossRef] [PubMed]

7. Nassal, M. HBV cccDNA: Viral persistence reservoir and key obstacle for a cure of chronic hepatitis B. Gut 2015, 64, 1972-1984. [CrossRef] [PubMed]

8. Moolla, N.; Kew, M.; Arbuthnot, P. Regulatory elements of hepatitis B virus transcription. J. Viral Hepat. 2002, 9, 323-331. [CrossRef] [PubMed]

9. Cattaneo, R.; Will, H.; Hernandez, N.; Schaller, H. Signals regulating hepatitis B surface antigen transcription. Nature 1983, 305, 336-338. [CrossRef] [PubMed]

10. Cattaneo, R.; Will, H.; Schaller, H. Hepatitis B virus transcription in the infected liver. EMBO J. 1984, 3, 2191-2196. [CrossRef] [PubMed]

11. Bartenschlager, R.; Schaller, H. The amino-terminal domain of the hepadnaviral P-gene encodes the terminal protein (genomelinked protein) believed to prime reverse transcription. EMBO J. 1988, 7, 4185-4192. [CrossRef] [PubMed]

12. Gish, R.G.; Given, B.D.; Lai, C.L.; Locarnini, S.A.; Lau, J.Y.; Lewis, D.L.; Schluep, T. Chronic hepatitis B: Virology, natural history, current management and a glimpse at future opportunities. Antivir. Res. 2015, 121, 47-58. [CrossRef]

13. Bartenschlager, R.; Schaller, H. Hepadnaviral assembly is initiated by polymerase binding to the encapsidation signal in the viral RNA genome. EMBO J. 1992, 11, 3413-3420. [CrossRef] [PubMed]

14. Summers, J; Mason, W.S. Replication of the genome of a hepatitis B-like virus by reverse transcription of an RNA intermediate. Cell 1982, 29, 403-415. [CrossRef]

15. Heermann, K.H.; Kruse, F.; Seifer, M.; Gerlich, W.H. Immunogenicity of the gene S and Pre-S domains in hepatitis B virions and HBsAg filaments. Intervirology 1987, 28, 14-25. [CrossRef] [PubMed]

16. Short, J.M.; Chen, S.; Roseman, A.M.; Butler, P.J.; Crowther, R.A. Structure of hepatitis B surface antigen from subviral tubes determined by electron cryomicroscopy. J. Mol. Biol. 2009, 390, 135-141. [CrossRef] [PubMed]

17. Hofmann, W.P.; Zeuzem, S. A new standard of care for the treatment of chronic HCV infection. Nat. Rev. Gastroenterol. Hepatol. 2011, 8, 257-264. [CrossRef] [PubMed]

18. Gotte, M.; Feld, J.J. Direct-acting antiviral agents for hepatitis C: Structural and mechanistic insights. Nat. Rev. Gastroenterol. Hepatol. 2016, 13, 338-351. [CrossRef] [PubMed]

19. European Association for the Study of the Liver. EASL Recommendations on Treatment of Hepatitis C 2018. J. Hepatol. 2018, 69, 461-511. [CrossRef] 
20. Lohmann, V.; Korner, F.; Koch, J.; Herian, U.; Theilmann, L.; Bartenschlager, R. Replication of subgenomic hepatitis C virus RNAs in a hepatoma cell line. Science 1999, 285, 110-113. [CrossRef]

21. Hao, W.; Herlihy, K.J.; Zhang, N.J.; Fuhrman, S.A.; Doan, C.; Patick, A.K.; Duggal, R. Development of a novel dicistronic reporter-selectable hepatitis C virus replicon suitable for high-throughput inhibitor screening. Antimicrob. Agents Chemother. 2007, 51, 95-102. [CrossRef]

22. Love, R.A.; Parge, H.E.; Wickersham, J.A.; Hostomsky, Z.; Habuka, N.; Moomaw, E.W.; Adachi, T.; Hostomska, Z. The crystal structure of hepatitis C virus NS3 proteinase reveals a trypsin-like fold and a structural zinc binding site. Cell 1996, 87, 331-342. [CrossRef]

23. Kim, J.L.; Morgenstern, K.A.; Lin, C.; Fox, T.; Dwyer, M.D.; Landro, J.A.; Chambers, S.P.; Markland, W.; Lepre, C.A.; O’Malley, E.T.; et al. Crystal structure of the hepatitis C virus NS3 protease domain complexed with a synthetic NS4A cofactor peptide. Cell 1996, 87, 343-355. [CrossRef]

24. Bressanelli, S.; Tomei, L.; Roussel, A.; Incitti, I.; Vitale, R.L.; Mathieu, M.; De Francesco, R.; Rey, F.A. Crystal structure of the RNA-dependent RNA polymerase of hepatitis C virus. Proc. Natl. Acad. Sci. USA 1999, 96, 13034-13039. [CrossRef] [PubMed]

25. Lesburg, C.A.; Cable, M.B.; Ferrari, E.; Hong, Z.; Mannarino, A.F.; Weber, P.C. Crystal structure of the RNA-dependent RNA polymerase from hepatitis C virus reveals a fully encircled active site. Nat. Struct. Biol. 1999, 6, 937-943. [CrossRef] [PubMed]

26. Penin, F.; Brass, V.; Appel, N.; Ramboarina, S.; Montserret, R.; Ficheux, D.; Blum, H.E.; Bartenschlager, R.; Moradpour, D. Structure and function of the membrane anchor domain of hepatitis $C$ virus nonstructural protein 5A. J. Biol. Chem. 2004, 279, 40835-40843. [CrossRef] [PubMed]

27. Revill, P.; Testoni, B.; Locarnini, S.; Zoulim, F. Global strategies are required to cure and eliminate HBV infection. Nat. Rev. Gastroenterol. Hepatol. 2016, 13, 239-248. [CrossRef] [PubMed]

28. Allen, M.I.; Deslauriers, M.; Andrews, C.W.; Tipples, G.A.; Walters, K.A.; Tyrrell, D.L.; Brown, N.; Condreay, L.D. Identification and characterization of mutations in hepatitis B virus resistant to lamivudine. Lamivudine Clinical Investigation Group. Hepatology 1998, 27, 1670-1677. [CrossRef]

29. Angus, P.; Vaughan, R.; Xiong, S.; Yang, H.; Delaney, W.; Gibbs, C.; Brosgart, C.; Colledge, D.; Edwards, R.; Ayres, A.; et al. Resistance to adefovir dipivoxil therapy associated with the selection of a novel mutation in the HBV polymerase. Gastroenterology 2003, 125, 292-297. [CrossRef]

30. Tenney, D.J.; Rose, R.E.; Baldick, C.J.; Pokornowski, K.A.; Eggers, B.J.; Fang, J.; Wichroski, M.J.; Xu, D.; Yang, J.; Wilber, R.B.; et al. Long-term monitoring shows hepatitis B virus resistance to entecavir in nucleoside-naive patients is rare through 5 years of therapy. Hepatology 2009, 49, 1503-1514. [CrossRef]

31. Lai, C.L.; Wong, D.; Ip, P.; Kopaniszen, M.; Seto, W.K.; Fung, J.; Huang, F.Y.; Lee, B.; Cullaro, G.; Chong, C.K.; et al. Reduction of covalently closed circular DNA with long-term nucleos(t)ide analogue treatment in chronic hepatitis B. J. Hepatol. 2017, 66, 275-281. [CrossRef]

32. Park, E.S.; Lee, A.R.; Kim, D.H.; Lee, J.H.; Yoo, J.J.; Ahn, S.H.; Sim, H.; Park, S.; Kang, H.S.; Won, J.; et al. Identification of a quadruple mutation that confers tenofovir resistance in chronic hepatitis B patients. J. Hepatol. 2019, 70, 1093-1102. [CrossRef]

33. Durantel, D.; Zoulim, F. New antiviral targets for innovative treatment concepts for hepatitis B virus and hepatitis delta virus. J. Hepatol. 2016, 64, S117-S131. [CrossRef] [PubMed]

34. Petersen, J.; Dandri, M.; Mier, W.; Lutgehetmann, M.; Volz, T.; von Weizsacker, F.; Haberkorn, U.; Fischer, L.; Pollok, J.M.; Erbes, B.; et al. Prevention of hepatitis B virus infection in vivo by entry inhibitors derived from the large envelope protein. Nat. Biotechnol. 2008, 26, 335-341. [CrossRef] [PubMed]

35. Volz, T.; Allweiss, L.; Ben, M.M.; Warlich, M.; Lohse, A.W.; Pollok, J.M.; Alexandrov, A.; Urban, S.; Petersen, J.; Lutgehetmann, M.; et al. The entry inhibitor Myrcludex-B efficiently blocks intrahepatic virus spreading in humanized mice previously infected with hepatitis B virus. J. Hepatol. 2013, 58, 861-867. [CrossRef] [PubMed]

36. Bogomolov, P.; Alexandrov, A.; Voronkova, N.; Macievich, M.; Kokina, K.; Petrachenkova, M.; Lehr, T.; Lempp, F.A.; Wedemeyer, H.; Haag, M.; et al. Treatment of chronic hepatitis D with the entry inhibitor myrcludex B: First results of a phase Ib/IIa study. J. Hepatol. 2016, 65, 490-498. [CrossRef]

37. Tavis, J.E.; Cheng, X.; Hu, Y.; Totten, M.; Cao, F.; Michailidis, E.; Aurora, R.; Meyers, M.J.; Jacobsen, E.J.; Parniak, M.A.; et al. The hepatitis $B$ virus ribonuclease $\mathrm{H}$ is sensitive to inhibitors of the human immunodeficiency virus ribonuclease $\mathrm{H}$ and integrase enzymes. PLoS Pathog. 2013, 9, e1003125. [CrossRef]

38. Tavis, J.E.; Lomonosova, E. The hepatitis B virus ribonuclease H as a drug target. Antivir. Res. 2015, 118, 132-138. [CrossRef]

39. Lomonosova, E.; Daw, J.; Garimallaprabhakaran, A.K.; Agyemang, N.B.; Ashani, Y.; Murelli, R.P.; Tavis, J.E. Efficacy and cytotoxicity in cell culture of novel alpha-hydroxytropolone inhibitors of hepatitis B virus ribonuclease H. Antivir. Res. 2017, 144, 164-172. [CrossRef]

40. Crowther, R.A.; Kiselev, N.A.; Bottcher, B.; Berriman, J.A.; Borisova, G.P.; Ose, V.; Pumpens, P. Three-dimensional structure of hepatitis B virus core particles determined by electron cryomicroscopy. Cell 1994, 77, 943-950. [CrossRef]

41. Wynne, S.A.; Crowther, R.A.; Leslie, A.G. The crystal structure of the human hepatitis B virus capsid. Mol. Cell 1999, 3, 771-780. [CrossRef]

42. Zlotnick, A.; Venkatakrishnan, B.; Tan, Z.; Lewellyn, E.; Turner, W.; Francis, S. Core protein: A pleiotropic keystone in the HBV lifecycle. Antivir. Res. 2015, 121, 82-93. [CrossRef] 
43. Yuen, M.F.; Gane, E.J.; Kim, D.J.; Weilert, F.; Yuen Chan, H.L.; Lalezari, J.; Hwang, S.G.; Nguyen, T.; Flores, O.; Hartman, G.; et al. Antiviral Activity, Safety, and Pharmacokinetics of Capsid Assembly Modulator NVR 3-778 in Patients with Chronic HBV Infection. Gastroenterology 2019, 156, 1392-1403.e1397. [CrossRef]

44. Zhao, N.; Jia, B.; Zhao, H.; Xu, J.; Sheng, X.; Luo, L.; Huang, Z.; Wang, X.; Ren, Q.; Zhang, Y.; et al. A First-in-Human Trial of GLS4, a Novel Inhibitor of Hepatitis B Virus Capsid Assembly, following Single- and Multiple-Ascending-Oral-Dose Studies with or without Ritonavir in Healthy Adult Volunteers. Antimicrob. Agents Chemother. 2019, 64. [CrossRef]

45. Zoulim, F.; Lenz, O.; Vandenbossche, J.J.; Talloen, W.; Verbinnen, T.; Moscalu, I.; Streinu-Cercel, A.; Bourgeois, S.; Buti, M.; Crespo, J.; et al. JNJ-56136379, an HBV Capsid Assembly Modulator, is Well-Tolerated and Has Antiviral Activity in a Phase 1 Study of Patients with Chronic Infection. Gastroenterology 2020. [CrossRef]

46. Yuen, M.F.; Agarwal, K.; Gane, E.J.; Schwabe, C.; Ahn, S.H.; Kim, D.J.; Lim, Y.S.; Cheng, W.; Sievert, W.; Visvanathan, K.; et al. Safety, pharmacokinetics, and antiviral effects of ABI-H0731, a hepatitis B virus core inhibitor: A randomised, placebo-controlled phase 1 trial. Lancet Gastroenterol. Hepatol. 2020, 5, 152-166. [CrossRef]

47. Bazinet, M.; Pantea, V.; Placinta, G.; Moscalu, I.; Cebotarescu, V.; Cojuhari, L.; Jimbei, P.; Iarovoi, L.; Smesnoi, V.; Musteata, T.; et al. Safety and Efficacy of 48 Weeks REP 2139 or REP 2165, Tenofovir Disoproxil, and Pegylated Interferon Alfa-2a in Patients With Chronic HBV Infection Naive to Nucleos(t)ide Therapy. Gastroenterology 2020, 158, 2180-2194. [CrossRef]

48. Guo, H.; Xu, C.; Zhou, T.; Block, T.M.; Guo, J.T. Characterization of the host factors required for hepadnavirus covalently closed circular (ccc) DNA formation. PLoS ONE 2012, 7, e43270. [CrossRef]

49. Guo, H.; Jiang, D.; Zhou, T.; Cuconati, A.; Block, T.M.; Guo, J.T. Characterization of the intracellular deproteinized relaxed circular DNA of hepatitis B virus: An intermediate of covalently closed circular DNA formation. J. Virol. 2007, 81, 12472-12484. [CrossRef] [PubMed]

50. Koniger, C.; Wingert, I.; Marsmann, M.; Rosler, C.; Beck, J.; Nassal, M. Involvement of the host DNA-repair enzyme TDP2 in formation of the covalently closed circular DNA persistence reservoir of hepatitis B viruses. Proc. Natl. Acad. Sci. USA 2014, 111, E4244-E4253. [CrossRef] [PubMed]

51. Kitamura, K.; Que, L.; Shimadu, M.; Koura, M.; Ishihara, Y.; Wakae, K.; Nakamura, T.; Watashi, K.; Wakita, T.; Muramatsu, M. Flap endonuclease 1 is involved in cccDNA formation in the hepatitis B virus. PLoS Pathog. 2018, 14, e1007124. [CrossRef] [PubMed]

52. Qi, Y.; Gao, Z.; Xu, G.; Peng, B.; Liu, C.; Yan, H.; Yao, Q.; Sun, G.; Liu, Y.; Tang, D.; et al. DNA Polymerase kappa Is a Key Cellular Factor for the Formation of Covalently Closed Circular DNA of Hepatitis B Virus. PLoS Pathog. 2016, 12, e1005893. [CrossRef]

53. Sheraz, M.; Cheng, J.; Tang, L.; Chang, J.; Guo, J.T. Cellular DNA Topoisomerases Are Required for the Synthesis of Hepatitis B Virus Covalently Closed Circular DNA. J. Virol. 2019, 93. [CrossRef] [PubMed]

54. Tang, L.; Sheraz, M.; McGrane, M.; Chang, J.; Guo, J.T. DNA Polymerase alpha is essential for intracellular amplification of hepatitis B virus covalently closed circular DNA. PLoS Pathog. 2019, 15, e1007742. [CrossRef] [PubMed]

55. Long, Q.; Yan, R.; Hu, J.; Cai, D.; Mitra, B.; Kim, E.S.; Marchetti, A.; Zhang, H.; Wang, S.; Liu, Y.; et al. The role of host DNA ligases in hepadnavirus covalently closed circular DNA formation. PLoS Pathog. 2017, 13, e1006784. [CrossRef] [PubMed]

56. Wei, L.; Ploss, A. Core components of DNA lagging strand synthesis machinery are essential for hepatitis B virus cccDNA formation. Nat. Microbiol. 2020, 5, 715-726. [CrossRef]

57. Allweiss, L.; Volz, T.; Giersch, K.; Kah, J.; Raffa, G.; Petersen, J.; Lohse, A.W.; Beninati, C.; Pollicino, T.; Urban, S.; et al. Proliferation of primary human hepatocytes and prevention of hepatitis B virus reinfection efficiently deplete nuclear cccDNA in vivo. Gut 2018, 67, 542-552. [CrossRef]

58. Qu, B.; Ni, Y.; Lempp, F.A.; Vondran, F.W.R.; Urban, S. T5 Exonuclease Hydrolysis of Hepatitis B Virus Replicative Intermediates Allows Reliable Quantification and Fast Drug Efficacy Testing of Covalently Closed Circular DNA by PCR. J. Virol. 2018, 92. [CrossRef]

59. Yang, W.; Summers, J. Infection of ducklings with virus particles containing linear double-stranded duck hepatitis B virus DNA: Illegitimate replication and reversion. J. Virol. 1998, 72, 8710-8717. [CrossRef]

60. Tu, T.; Budzinska, M.A.; Shackel, N.A.; Urban, S. HBV DNA Integration: Molecular Mechanisms and Clinical Implications. Viruses 2017, 9, 75. [CrossRef]

61. Yang, W.; Summers, J. Integration of hepadnavirus DNA in infected liver: Evidence for a linear precursor. J. Virol. 1999, 73, 9710-9717. [CrossRef] [PubMed]

62. Summers, J.; Mason, W.S. Residual integrated viral DNA after hepadnavirus clearance by nucleoside analog therapy. Proc. Natl. Acad. Sci. USA 2004, 101, 638-640. [CrossRef]

63. Tu, T.; Budzinska, M.A.; Vondran, F.W.R.; Shackel, N.A.; Urban, S. Hepatitis B Virus DNA Integration Occurs Early in the Viral Life Cycle in an In Vitro Infection Model via Sodium Taurocholate Cotransporting Polypeptide-Dependent Uptake of Enveloped Virus Particles. J. Virol. 2018, 92. [CrossRef]

64. Bill, C.A.; Summers, J. Genomic DNA double-strand breaks are targets for hepadnaviral DNA integration. Proc. Natl. Acad. Sci. USA 2004, 101, 11135-11140. [CrossRef]

65. Alexander, J.J.; Bey, E.M.; Geddes, E.W.; Lecatsas, G. Establishment of a continuously growing cell line from primary carcinoma of the liver. South Afr. Med. J. 1976, 50, 2124-2128.

66. Edman, J.C.; Gray, P.; Valenzuela, P.; Rall, L.B.; Rutter, W.J. Integration of hepatitis B virus sequences and their expression in a human hepatoma cell. Nature 1980, 286, 535-538. [CrossRef] 
67. Twist, E.M.; Clark, H.F.; Aden, D.P.; Knowles, B.B.; Plotkin, S.A. Integration pattern of hepatitis B virus DNA sequences in human hepatoma cell lines. J. Virol. 1981, 37, 239-243. [CrossRef]

68. Meyer, J.L.; Fournier, J.G.; Bouteille, M. Expression of integrated hepatitis B virus DNA in PLC/PRF/5, Hep 3B, and L6EC3 cell lines detected by in situ hybridisation. Med. Biol. 1986, 64, 367-371.

69. Schluter, V.; Meyer, M.; Hofschneider, P.H.; Koshy, R.; Caselmann, W.H. Integrated hepatitis B virus X and 3' truncated preS/S sequences derived from human hepatomas encode functionally active transactivators. Oncogene 1994, 9, 3335-3344. [PubMed]

70. Shamay, M.; Agami, R.; Shaul, Y. HBV integrants of hepatocellular carcinoma cell lines contain an active enhancer. Oncogene 2001, 20, 6811-6819. [CrossRef] [PubMed]

71. Lau, C.C.; Sun, T.; Ching, A.K.; He, M.; Li, J.W.; Wong, A.M.; Co, N.N.; Chan, A.W.; Li, P.S.; Lung, R.W.; et al. Viral-human chimeric transcript predisposes risk to liver cancer development and progression. Cancer Cell 2014, 25, 335-349. [CrossRef]

72. Liang, H.W.; Wang, N.; Wang, Y.; Wang, F.; Fu, Z.; Yan, X.; Zhu, H.; Diao, W.; Ding, Y.; Chen, X.; et al. Hepatitis B virus-human chimeric transcript HBx-LINE1 promotes hepatic injury via sequestering cellular microRNA-122. J. Hepatol. 2016, 64, 278-291. [CrossRef] [PubMed]

73. Belloni, L.; Pollicino, T.; De Nicola, F.; Guerrieri, F.; Raffa, G.; Fanciulli, M.; Raimondo, G.; Levrero, M. Nuclear HBx binds the HBV minichromosome and modifies the epigenetic regulation of cccDNA function. Proc. Natl. Acad. Sci. USA 2009, 106, 19975-19979. [CrossRef] [PubMed]

74. Bock, C.T.; Schwinn, S.; Locarnini, S.; Fyfe, J.; Manns, M.P.; Trautwein, C.; Zentgraf, H. Structural organization of the hepatitis B virus minichromosome. J. Mol. Biol. 2001, 307, 183-196. [CrossRef] [PubMed]

75. Pollicino, T.; Belloni, L.; Raffa, G.; Pediconi, N.; Squadrito, G.; Raimondo, G.; Levrero, M. Hepatitis B virus replication is regulated by the acetylation status of hepatitis B virus cccDNA-bound H3 and H4 histones. Gastroenterology 2006, 130, 823-837. [CrossRef] [PubMed]

76. Tropberger, P.; Mercier, A.; Robinson, M.; Zhong, W.; Ganem, D.E.; Holdorf, M. Mapping of histone modifications in episomal HBV cccDNA uncovers an unusual chromatin organization amenable to epigenetic manipulation. Proc. Natl. Acad. Sci. USA 2015, 112, E5715-E5724. [CrossRef] [PubMed]

77. Chong, C.K.; Cheng, C.Y.S.; Tsoi, S.Y.J.; Huang, F.Y.; Liu, F.; Seto, W.K.; Lai, C.L.; Yuen, M.F.; Wong, D.K. Role of hepatitis B core protein in HBV transcription and recruitment of histone acetyltransferases to cccDNA minichromosome. Antivir. Res. 2017, 144, 1-7. [CrossRef] [PubMed]

78. Quasdorff, M.; Protzer, U. Control of hepatitis B virus at the level of transcription. J. Viral Hepat. 2010, 17, 527-536. [CrossRef]

79. Oropeza, C.E.; Tarnow, G.; Sridhar, A.; Taha, T.Y.; Shalaby, R.E.; McLachlan, A. The Regulation of HBV Transcription and Replication. Adv. Exp. Med. Biol. 2020, 1179, 39-69. [CrossRef]

80. Turton, K.L.; Meier-Stephenson, V.; Badmalia, M.D.; Coffin, C.S.; Patel, T.R. Host Transcription Factors in Hepatitis B Virus RNA Synthesis. Viruses 2020, 12, 160. [CrossRef]

81. Li, J.; Xu, Z.; Zheng, Y.; Johnson, D.L.; Ou, J.H. Regulation of hepatocyte nuclear factor 1 activity by wild-type and mutant hepatitis B virus $X$ proteins. J. Virol. 2002, 76, 5875-5881. [CrossRef] [PubMed]

82. Zheng, Y.; Li, J.; Ou, J.H. Regulation of hepatitis B virus core promoter by transcription factors HNF1 and HNF4 and the viral X protein. J. Virol. 2004, 78, 6908-6914. [CrossRef]

83. Zhou, D.X.; Yen, T.S. The ubiquitous transcription factor Oct-1 and the liver-specific factor HNF-1 are both required to activate transcription of a hepatitis B virus promoter. Mol. Cell Biol. 1991, 11, 1353-1359. [CrossRef] [PubMed]

84. Lin, J.; Gu, C.; Shen, Z.; Liu, Y.; Wang, W.; Tao, S.; Cui, X.; Liu, J.; Xie, Y. Hepatocyte nuclear factor 1alpha downregulates HBV gene expression and replication by activating the NF-kappaB signaling pathway. PLoS ONE 2017, 12, e0174017. [CrossRef]

85. Li, M.; Xie, Y.; Wu, X.; Kong, Y.; Wang, Y. HNF3 binds and activates the second enhancer, ENII, of hepatitis B virus. Virology 1995, 214, 371-378. [CrossRef] [PubMed]

86. Raney, A.K.; Zhang, P.; McLachlan, A. Regulation of transcription from the hepatitis B virus large surface antigen promoter by hepatocyte nuclear factor 3. J. Virol. 1995, 69, 3265-3272. [CrossRef] [PubMed]

87. Chen, M.; Hieng, S.; Qian, X.; Costa, R.; Ou, J.H. Regulation of hepatitis B virus ENI enhancer activity by hepatocyte-enriched transcription factor HNF3. Virology 1994, 205, 127-132. [CrossRef] [PubMed]

88. Guo, W.; Chen, M.; Yen, T.S.; Ou, J.H. Hepatocyte-specific expression of the hepatitis B virus core promoter depends on both positive and negative regulation. Mol. Cell Biol. 1993, 13, 443-448. [CrossRef] [PubMed]

89. Hao, R.; He, J.; Liu, X.; Gao, G.; Liu, D.; Cui, L.; Yu, G.; Yu, W.; Chen, Y.; Guo, D. Inhibition of hepatitis B virus gene expression and replication by hepatocyte nuclear factor 6. J. Virol. 2015, 89, 4345-4355. [CrossRef]

90. Hwang-Verslues, W.W.; Sladek, F.M. HNF4alpha-role in drug metabolism and potential drug target? Curr. Opin. Pharmacol. 2010, 10, 698-705. [CrossRef] [PubMed]

91. Robinson-Rechavi, M.; Escriva Garcia, H.; Laudet, V. The nuclear receptor superfamily. J. Cell Sci. 2003, 116, 585-586. [CrossRef]

92. Chandra, V.; Huang, P.; Hamuro, Y.; Raghuram, S.; Wang, Y.; Burris, T.P.; Rastinejad, F. Structure of the intact PPAR-gamma-RXRnuclear receptor complex on DNA. Nature 2008, 456, 350-356. [CrossRef]

93. Lou, X.; Toresson, G.; Benod, C.; Suh, J.H.; Philips, K.J.; Webb, P.; Gustafsson, J.A. Structure of the retinoid X receptor alpha-liver X receptor beta (RXRalpha-LXRbeta) heterodimer on DNA. Nat. Struct. Mol. Biol. 2014, 21, 277-281. [CrossRef] [PubMed]

94. Zheng, W.; Lu, Y.; Tian, S.; Ma, F.; Wei, Y.; Xu, S.; Li, Y. Structural insights into the heterodimeric complex of the nuclear receptors FXR and RXR. J. Biol. Chem. 2018, 293, 12535-12541. [CrossRef] 
95. Chong, C.K.; Cheng, C.Y.S.; Tsoi, S.Y.J.; Huang, F.Y.; Liu, F.; Fung, J.; Seto, W.K.; Lai, K.K.; Lai, C.L.; Yuen, M.F.; et al. HBV X protein mutations affect HBV transcription and association of histone-modifying enzymes with covalently closed circular DNA. Sci. Rep. 2020, 10, 802. [CrossRef] [PubMed]

96. Lucifora, J.; Arzberger, S.; Durantel, D.; Belloni, L.; Strubin, M.; Levrero, M.; Zoulim, F.; Hantz, O.; Protzer, U. Hepatitis B virus X protein is essential to initiate and maintain virus replication after infection. J. Hepatol. 2011, 55, 996-1003. [CrossRef] [PubMed]

97. Li, T.; Robert, E.I.; van Breugel, P.C.; Strubin, M.; Zheng, N. A promiscuous alpha-helical motif anchors viral hijackers and substrate receptors to the CUL4-DDB1 ubiquitin ligase machinery. Nat. Struct. Mol. Biol. 2010, 17, 105-111. [CrossRef]

98. Decorsiere, A.; Mueller, H.; van Breugel, P.C.; Abdul, F.; Gerossier, L.; Beran, R.K.; Livingston, C.M.; Niu, C.; Fletcher, S.P.; Hantz, O.; et al. Hepatitis B virus X protein identifies the Smc5/ 6 complex as a host restriction factor. Nature 2016, 531, 386-389. [CrossRef]

99. Murphy, C.M.; Xu, Y.; Li, F.; Nio, K.; Reszka-Blanco, N.; Li, X.; Wu, Y.; Yu, Y.; Xiong, Y.; Su, L. Hepatitis B Virus X Protein Promotes Degradation of SMC5/6 to Enhance HBV Replication. Cell Rep. 2016, 16, 2846-2854. [CrossRef]

100. van Breugel, P.C.; Robert, E.I.; Mueller, H.; Decorsiere, A.; Zoulim, F.; Hantz, O.; Strubin, M. Hepatitis B virus X protein stimulates gene expression selectively from extrachromosomal DNA templates. Hepatology 2012, 56, 2116-2124. [CrossRef] [PubMed]

101. Budzinska, M.A.; Shackel, N.A.; Urban, S.; Tu, T. Sequence analysis of integrated hepatitis B virus DNA during HBeAgseroconversion. Emerg. Microbes Infect. 2018, 7, 142. [CrossRef]

102. Budzinska, M.A.; Shackel, N.A.; Urban, S.; Tu, T. Cellular Genomic Sites of Hepatitis B Virus DNA Integration. Genes 2018, 9, 365. [CrossRef] [PubMed]

103. Wooddell, C.I.; Yuen, M.F.; Chan, H.L.; Gish, R.G.; Locarnini, S.A.; Chavez, D.; Ferrari, C.; Given, B.D.; Hamilton, J.; Kanner, S.B.; et al. RNAi-based treatment of chronically infected patients and chimpanzees reveals that integrated hepatitis B virus DNA is a source of HBsAg. Sci. Transl. Med. 2017, 9. [CrossRef] [PubMed]

104. Takada, S.; Koike, K. Trans-activation function of a 3' truncated X gene-cell fusion product from integrated hepatitis B virus DNA in chronic hepatitis tissues. Proc. Natl. Acad. Sci. USA 1990, 87, 5628-5632. [CrossRef] [PubMed]

105. Wei, Y.; Etiemble, J.; Fourel, G.; Vitvitski-Trepo, L.; Buendia, M.A. Hepadna virus integration generates virus-cell cotranscripts carrying 3' truncated X genes in human and woodchuck liver tumors. J. Med. Virol. 1995, 45, 82-90. [CrossRef]

106. Kumar, V.; Jayasuryan, N.; Kumar, R. A truncated mutant (residues 58-140) of the hepatitis B virus X protein retains transactivation function. Proc. Natl. Acad. Sci. USA 1996, 93, 5647-5652. [CrossRef]

107. Jiang, Z.; Jhunjhunwala, S.; Liu, J.; Haverty, P.M.; Kennemer, M.I.; Guan, Y.; Lee, W.; Carnevali, P.; Stinson, J.; Johnson, S.; et al. The effects of hepatitis B virus integration into the genomes of hepatocellular carcinoma patients. Genome Res. 2012, 22, 593-601. [CrossRef]

108. Sung, W.K.; Zheng, H.; Li, S.; Chen, R.; Liu, X.; Li, Y.; Lee, N.P.; Lee, W.H.; Ariyaratne, P.N.; Tennakoon, C.; et al. Genome-wide survey of recurrent HBV integration in hepatocellular carcinoma. Nat. Genet. 2012, 44, 765-769. [CrossRef]

109. Li, X.; Zhang, J.; Yang, Z.; Kang, J.; Jiang, S.; Zhang, T.; Chen, T.; Li, M.; Lv, Q.; Chen, X.; et al. The function of targeted host genes determines the oncogenicity of HBV integration in hepatocellular carcinoma. J. Hepatol. 2014, 60, 975-984. [CrossRef]

110. Belloni, L.; Allweiss, L.; Guerrieri, F.; Pediconi, N.; Volz, T.; Pollicino, T.; Petersen, J.; Raimondo, G.; Dandri, M.; Levrero, M. IFN-alpha inhibits HBV transcription and replication in cell culture and in humanized mice by targeting the epigenetic regulation of the nuclear cccDNA minichromosome. J. Clin. Invest. 2012, 122, 529-537. [CrossRef]

111. Liu, F.; Campagna, M.; Qi, Y.; Zhao, X.; Guo, F.; Xu, C.; Li, S.; Li, W.; Block, T.M.; Chang, J.; et al. Alpha-interferon suppresses hepadnavirus transcription by altering epigenetic modification of cccDNA minichromosomes. PLoS Pathog. 2013, 9, e1003613. [CrossRef]

112. Palumbo, G.A.; Scisciani, C.; Pediconi, N.; Lupacchini, L.; Alfalate, D.; Guerrieri, F.; Calvo, L.; Salerno, D.; Di Cocco, S.; Levrero, M.; et al. IL6 Inhibits HBV Transcription by Targeting the Epigenetic Control of the Nuclear cccDNA Minichromosome. PLoS ONE 2015, 10, e0142599. [CrossRef]

113. Hosel, M.; Quasdorff, M.; Ringelhan, M.; Kashkar, H.; Debey-Pascher, S.; Sprinzl, M.F.; Bockmann, J.H.; Arzberger, S.; Webb, D.; von Olshausen, G.; et al. Hepatitis B Virus Activates Signal Transducer and Activator of Transcription 3 Supporting Hepatocyte Survival and Virus Replication. Cell Mol. Gastroenterol. Hepatol. 2017, 4, 339-363. [CrossRef] [PubMed]

114. Liang, G.; Kitamura, K.; Wang, Z.; Liu, G.; Chowdhury, S.; Fu, W.; Koura, M.; Wakae, K.; Honjo, T.; Muramatsu, M. RNA editing of hepatitis B virus transcripts by activation-induced cytidine deaminase. Proc. Natl. Acad. Sci. USA 2013, 110, 2246-2251. [CrossRef]

115. Liang, G.; Liu, G.; Kitamura, K.; Wang, Z.; Chowdhury, S.; Monjurul, A.M.; Wakae, K.; Koura, M.; Shimadu, M.; Kinoshita, K.; et al. TGF-beta suppression of HBV RNA through AID-dependent recruitment of an RNA exosome complex. PLoS Pathog. 2015, 11, e1004780. [CrossRef]

116. Hong, M.H.; Chou, Y.C.; Wu, Y.C.; Tsai, K.N.; Hu, C.P.; Jeng, K.S.; Chen, M.L.; Chang, C. Transforming growth factor-beta1 suppresses hepatitis B virus replication by the reduction of hepatocyte nuclear factor-4alpha expression. PLoS ONE 2012, 7, e30360. [CrossRef]

117. Li, B.; Wang, Y.; Shen, F.; Wu, M.; Li, Y.; Fang, Z.; Ye, J.; Wang, L.; Gao, L.; Yuan, Z.; et al. Identification of Retinoic Acid Receptor Agonists as Potent Hepatitis B Virus Inhibitors via a Drug Repurposing Screen. Antimicrob. Agents Chemother. 2018, 62. [CrossRef] [PubMed] 
118. Nkongolo, S.; Nussbaum, L.; Lempp, F.A.; Wodrich, H.; Urban, S.; Ni, Y. The retinoic acid receptor (RAR) alpha-specific agonist Am80 (tamibarotene) and other RAR agonists potently inhibit hepatitis B virus transcription from cccDNA. Antivir. Res. 2019, 168, 146-155. [CrossRef] [PubMed]

119. Birkus, G.; Snyder, C.; Jordan, R.; Kobayashi, T.; Dick, R.; Puscau, V.; Li, L.; Ramirez, R.; Willkom, M.; Morikawa, Y.; et al. Anti-HBV activity of retinoid drugs in vitro versus in vivo. Antivir. Res. 2019, 169, 104538. [CrossRef]

120. Song, M.; Sun, Y.; Tian, J.; He, W.; Xu, G.; Jing, Z.; Li, W. Silencing Retinoid X Receptor Alpha Expression Enhances Early-Stage Hepatitis B Virus Infection In Cell Cultures. J. Virol. 2018, 92. [CrossRef]

121. Radreau, P.; Porcherot, M.; Ramiere, C.; Mouzannar, K.; Lotteau, V.; Andre, P. Reciprocal regulation of farnesoid X receptor alpha activity and hepatitis B virus replication in differentiated HepaRG cells and primary human hepatocytes. FASEB J. 2016, 30, 3146-3154. [CrossRef] [PubMed]

122. Mouzannar, K.; Fusil, F.; Lacombe, B.; Ollivier, A.; Menard, C.; Lotteau, V.; Cosset, F.L.; Ramiere, C.; Andre, P. Farnesoid X receptor-alpha is a proviral host factor for hepatitis B virus that is inhibited by ligands in vitro and in vivo. FASEB J. 2019, 33, 2472-2483. [CrossRef] [PubMed]

123. Darteil, R.; Joly, S.; Radreau, P.; Porcherot, M.; Vonderscher, J.; Scalfaro, P.; Meldrum, E.; Andre, P. In Vitro Characterization of Eyp001 a Novel, Potent and Selective Fxr Agonist Entering Phase 2 Clinical Trials in Chronic Hepatitis B. Hepatology 2019, 70, 60a.

124. Zeng, J.; Wu, D.; Hu, H.; Young, J.A.T.; Yan, Z.; Gao, L. Activation of the liver X receptor pathway inhibits HBV replication in primary human hepatocytes. Hepatology 2020, 72, 1935-1948. [CrossRef]

125. Bray, M.; Andrei, G.; Ballana, E.; Carter, K.; Durantel, D.; Gentry, B.; Janeba, Z.; Moffat, J.; Oomen, C.J.; Tarbet, B.; et al. Meeting report: 31(st) International Conference on Antiviral Research. Antivir. Res. 2018, 158, 88-102. [CrossRef] [PubMed]

126. Qu, B.; Leuthold, M.; Sonnabend, J.; Urban, S. SAT-192-Targeting the HBx-DDB1-Cullin complex inhibits transcription from HBV covalently closed circular DNA in susceptible hepatoma cells. J. Hepatol. 2019, 70, e714-e715. [CrossRef]

127. Sekiba, K.; Otsuka, M.; Ohno, M.; Yamagami, M.; Kishikawa, T.; Seimiya, T.; Suzuki, T.; Tanaka, E.; Ishibashi, R.; Funato, K.; et al. Pevonedistat, a Neuronal Precursor Cell-Expressed Developmentally Down-Regulated Protein 8-Activating Enzyme Inhibitor, Is a Potent Inhibitor of Hepatitis B Virus. Hepatology 2019, 69, 1903-1915. [CrossRef]

128. Sekiba, K.; Otsuka, M.; Ohno, M.; Yamagami, M.; Kishikawa, T.; Suzuki, T.; Ishibashi, R.; Seimiya, T.; Tanaka, E.; Koike, K. Inhibition of HBV Transcription From cccDNA With Nitazoxanide by Targeting the HBx-DDB1 Interaction. Cell Mol. Gastroenterol. Hepatol. 2019, 7, 297-312. [CrossRef]

129. Rossignol, J.F.; Brechot, C. A Pilot Clinical Trial of Nitazoxanide in the Treatment of Chronic Hepatitis B. Hepatol. Commun. 2019, 3, 744-747. [CrossRef]

130. Xia, Y.; Protzer, U. Control of Hepatitis B Virus by Cytokines. Viruses 2017, 9, 18. [CrossRef]

131. Lucifora, J.; Xia, Y.; Reisinger, F.; Zhang, K.; Stadler, D.; Cheng, X.; Sprinzl, M.F.; Koppensteiner, H.; Makowska, Z.; Volz, T.; et al. Specific and nonhepatotoxic degradation of nuclear hepatitis B virus cccDNA. Science 2014, 343, 1221-1228. [CrossRef] [PubMed]

132. Gao, B.; Duan, Z.; Xu, W.; Xiong, S. Tripartite motif-containing 22 inhibits the activity of hepatitis B virus core promoter, which is dependent on nuclear-located RING domain. Hepatology 2009, 50, 424-433. [CrossRef]

133. Nakshatri, H.; Bhat-Nakshatri, P. Multiple parameters determine the specificity of transcriptional response by nuclear receptors HNF-4, ARP-1, PPAR, RAR and RXR through common response elements. Nucleic Acids Res. 1998, 26, 2491-2499. [CrossRef]

134. Tsukuda, S.; Watashi, K.; Iwamoto, M.; Suzuki, R.; Aizaki, H.; Okada, M.; Sugiyama, M.; Kojima, S.; Tanaka, Y.; Mizokami, M.; et al. Dysregulation of retinoic acid receptor diminishes hepatocyte permissiveness to hepatitis B virus infection through modulation of sodium taurocholate cotransporting polypeptide (NTCP) expression. J. Biol. Chem. 2015, 290, 5673-5684. [CrossRef]

135. Garcia, A.D.; Ostapchuk, P.; Hearing, P. Functional interaction of nuclear factors EF-C, HNF-4, and RXR alpha with hepatitis B virus enhancer I. J. Virol 1993, 67, 3940-3950. [CrossRef]

136. Huan, B.; Siddiqui, A. Retinoid X receptor RXR alpha binds to and trans-activates the hepatitis B virus enhancer. Proc. Natl. Acad. Sci. USA 1992, 89, 9059-9063. [CrossRef] [PubMed]

137. Makishima, M.; Okamoto, A.Y.; Repa, J.J.; Tu, H.; Learned, R.M.; Luk, A.; Hull, M.V.; Lustig, K.D.; Mangelsdorf, D.J.; Shan, B. Identification of a nuclear receptor for bile acids. Science 1999, 284, 1362-1365. [CrossRef] [PubMed]

138. Parks, D.J.; Blanchard, S.G.; Bledsoe, R.K.; Chandra, G.; Consler, T.G.; Kliewer, S.A.; Stimmel, J.B.; Willson, T.M.; Zavacki, A.M.; Moore, D.D.; et al. Bile acids: Natural ligands for an orphan nuclear receptor. Science 1999, 284, 1365-1368. [CrossRef] [PubMed]

139. Laffitte, B.A.; Kast, H.R.; Nguyen, C.M.; Zavacki, A.M.; Moore, D.D.; Edwards, P.A. Identification of the DNA binding specificity and potential target genes for the farnesoid X-activated receptor. J. Biol. Chem. 2000, 275, 10638-10647. [CrossRef] [PubMed]

140. Ramiere, C.; Scholtes, C.; Diaz, O.; Icard, V.; Perrin-Cocon, L.; Trabaud, M.A.; Lotteau, V.; Andre, P. Transactivation of the hepatitis B virus core promoter by the nuclear receptor FXRalpha. J. Virol. 2008, 82, 10832-10840. [CrossRef]

141. Zollner, G.; Fickert, P.; Silbert, D.; Fuchsbichler, A.; Stumptner, C.; Zatloukal, K.; Denk, H.; Trauner, M. Induction of short heterodimer partner 1 precedes downregulation of Ntcp in bile duct-ligated mice. Am. J. Physiol. Gastrointest. Liver Physiol. 2002, 282, G184-G191. [CrossRef]

142. Wang, B.; Tontonoz, P. Liver X receptors in lipid signalling and membrane homeostasis. Nat. Rev. Endocrinol. $2018,14,452-463$. [CrossRef]

143. Korba, B.E.; Montero, A.B.; Farrar, K.; Gaye, K.; Mukerjee, S.; Ayers, M.S.; Rossignol, J.F. Nitazoxanide, tizoxanide and other thiazolides are potent inhibitors of hepatitis B virus and hepatitis C virus replication. Antivir. Res. 2008, 77, 56-63. [CrossRef] 
144. Leong, C.R.; Funami, K.; Oshiumi, H.; Mengao, D.; Takaki, H.; Matsumoto, M.; Aly, H.H.; Watashi, K.; Chayama, K.; Seya, T. Interferon-stimulated gene of $20 \mathrm{kDa}$ protein (ISG20) degrades RNA of hepatitis B virus to impede the replication of HBV in vitro and in vivo. Oncotarget 2016, 7, 68179-68193. [CrossRef] [PubMed]

145. Liu, Y.; Nie, H.; Mao, R.; Mitra, B.; Cai, D.; Yan, R.; Guo, J.T.; Block, T.M.; Mechti, N.; Guo, H. Interferon-inducible ribonuclease ISG20 inhibits hepatitis B virus replication through directly binding to the epsilon stem-loop structure of viral RNA. PLoS Pathog. 2017, 13, e1006296. [CrossRef]

146. Imam, H.; Kim, G.W.; Mir, S.A.; Khan, M.; Siddiqui, A. Interferon-stimulated gene 20 (ISG20) selectively degrades N6methyladenosine modified Hepatitis B Virus transcripts. PLoS Pathog. 2020, 16, e1008338. [CrossRef] [PubMed]

147. Chen, E.Q.; Dai, J.; Bai, L.; Tang, H. The efficacy of zinc finger antiviral protein against hepatitis B virus transcription and replication in tansgenic mouse model. Virol J. 2015, 12, 25. [CrossRef] [PubMed]

148. Mao, R.; Nie, H.; Cai, D.; Zhang, J.; Liu, H.; Yan, R.; Cuconati, A.; Block, T.M.; Guo, J.T.; Guo, H. Inhibition of hepatitis B virus replication by the host zinc finger antiviral protein. PLoS Pathog. 2013, 9, e1003494. [CrossRef] [PubMed]

149. Li, J.; Lin, S.; Chen, Q.; Peng, L.; Zhai, J.; Liu, Y.; Yuan, Z. Inhibition of hepatitis B virus replication by MyD88 involves accelerated degradation of pregenomic RNA and nuclear retention of pre-S/S RNAs. J. Virol. 2010, 84, 6387-6399. [CrossRef]

150. Gordien, E.; Rosmorduc, O.; Peltekian, C.; Garreau, F.; Brechot, C.; Kremsdorf, D. Inhibition of hepatitis B virus replication by the interferon-inducible MxA protein. J. Virol. 2001, 75, 2684-2691. [CrossRef]

151. Li, N.; Zhang, L.; Chen, L.; Feng, W.; Xu, Y.; Chen, F.; Liu, X.; Chen, Z.; Liu, W. MxA inhibits hepatitis B virus replication by interaction with hepatitis B core antigen. Hepatology 2012, 56, 803-811. [CrossRef]

152. Kim, D.; Lee, Y.S.; Jung, S.J.; Yeo, J.; Seo, J.J.; Lee, Y.Y.; Lim, J.; Chang, H.; Song, J.; Yang, J.; et al. Viral hijacking of the TENT4-ZCCHC14 complex protects viral RNAs via mixed tailing. Nat. Struct. Mol. Biol. 2020, 27, 581-588. [CrossRef] [PubMed]

153. Mueller, H.; Lopez, A.; Tropberger, P.; Wildum, S.; Schmaler, J.; Pedersen, L.; Han, X.; Wang, Y.; Ottosen, S.; Yang, S.; et al PAPD5/7 Are Host Factors That Are Required for Hepatitis B Virus RNA Stabilization. Hepatology 2019, 69, 1398-1411. [CrossRef] [PubMed]

154. Mueller, H.; Wildum, S.; Luangsay, S.; Walther, J.; Lopez, A.; Tropberger, P.; Ottaviani, G.; Lu, W.; Parrott, N.J.; Zhang, J.D.; et al. A novel orally available small molecule that inhibits hepatitis B virus expression. J. Hepatol. 2018, 68, 412-420. [CrossRef]

155. Hyrina, A.; Jones, C.; Chen, D.; Clarkson, S.; Cochran, N.; Feucht, P.; Hoffman, G.; Lindeman, A.; Russ, C.; Sigoillot, F.; et al. A Genome-wide CRISPR Screen Identifies ZCCHC14 as a Host Factor Required for Hepatitis B Surface Antigen Production. Cell Rep. 2019, 29, 2970-2978.e2976. [CrossRef] [PubMed]

156. Zhou, T.; Block, T.; Liu, F.; Kondratowicz, A.S.; Sun, L.; Rawat, S.; Branson, J.; Guo, F.; Steuer, H.M.; Liang, H.; et al. HBsAg mRNA degradation induced by a dihydroquinolizinone compound depends on the HBV posttranscriptional regulatory element. Antivir. Res. 2018, 149, 191-201. [CrossRef]

157. Niu, C.; Li, L.; Daffis, S.; Lucifora, J.; Bonnin, M.; Maadadi, S.; Salas, E.; Chu, R.; Ramos, H.; Livingston, C.M.; et al. Toll-like receptor 7 agonist GS-9620 induces prolonged inhibition of HBV via a type I interferon-dependent mechanism. J. Hepatol. 2018, 68, 922-931. [CrossRef]

158. Li, L.; Barry, V.; Daffis, S.; Niu, C.; Huntzicker, E.; French, D.M.; Mikaelian, I.; Lanford, R.E.; Delaney, W.E., 4th; Fletcher, S.P. Anti-HBV response to toll-like receptor 7 agonist GS-9620 is associated with intrahepatic aggregates of T cells and B cells. J. Hepatol. 2018, 68, 912-921. [CrossRef] [PubMed]

159. Boni, C.; Vecchi, A.; Rossi, M.; Laccabue, D.; Giuberti, T.; Alfieri, A.; Lampertico, P.; Grossi, G.; Facchetti, F.; Brunetto, M.R.; et al. TLR7 Agonist Increases Responses of Hepatitis B Virus-Specific T Cells and Natural Killer Cells in Patients With Chronic Hepatitis B Treated With Nucleos(T)Ide Analogues. Gastroenterology 2018, 154, 1764-1777.e1767. [CrossRef]

160. Amin, O.E.; Colbeck, E.; Daffis, S.; Pattabiraman, D.; Sitali, C.; Rosenberg, W.; Fletcher, S.; Maini, M.; Pallett, L.J. FRI-132-In vitro modulation by TLR8 agonist GS-9688 of multiple regulatory cell types in patients with chronic hepatitis B. J. Hepatol. 2019, 70. [CrossRef]

161. Daffis, S.; Morar, M.; Pattabiraman, D.; Voitenleitner, C.; Fletcher, S.; Javanbakht, H. Cytokine-dependent activation of MAIT cells by the TLR8 agonist GS-9688 but not the TLR7 agonist GS-9620. J. Hepatol. 2018, 68. [CrossRef]

162. Daffis, S.; Ramakrishnan, D.; Niu, C.; Zheng, J.; Santos, R.; Mish, M.; Chin, G.; Aktoudianakis, V.; Metobo, S.; Pyun, H.J.; et al. In vitro and in vivo characterization of the selective toll-like receptor 8 agonist GS-9688. J. Hepatol. 2017, 66. [CrossRef]

163. Korolowicz, K.E.; Iyer, R.P.; Czerwinski, S.; Suresh, M.; Yang, J.; Padmanabhan, S.; Sheri, A.; Pandey, R.K.; Skell, J.; Marquis, J.K.; et al. Antiviral Efficacy and Host Innate Immunity Associated with SB 9200 Treatment in the Woodchuck Model of Chronic Hepatitis B. PLoS ONE 2016, 11, e0161313. [CrossRef] [PubMed]

164. Mani, N.; Li, A.H.L.; Ardzinski, A.; Bailey, L.; Phelps, J.R.; Burns, R.; Chiu, T.; Cole, A.G.; Cuconati, A.; Dorsey, B.D.; et al. Preclinical antiviral drug combination studies utilizing novel orally bioavailable investigational agents for chronic hepatitis $B$ infection: AB-506, a next generation HBV capsid inhibitor, and AB-452, a HBV RNA destabilizer. J. Hepatol. 2018, 68. [CrossRef]

165. McCaffrey, A.P.; Nakai, H.; Pandey, K.; Huang, Z.; Salazar, F.H.; Xu, H.; Wieland, S.F.; Marion, P.L.; Kay, M.A. Inhibition of hepatitis B virus in mice by RNA interference. Nat. Biotechnol. 2003, 21, 639-644. [CrossRef]

166. Uprichard, S.L. The therapeutic potential of RNA interference. FEBS Lett. 2005, 579, 5996-6007. [CrossRef]

167. Uprichard, S.L.; Boyd, B.; Althage, A.; Chisari, F.V. Clearance of hepatitis B virus from the liver of transgenic mice by short hairpin RNAs. Proc. Natl. Acad. Sci. USA 2005, 102, 773-778. [CrossRef] 
168. Javanbakht, H.; Mueller, H.; Walther, J.; Zhou, X.; Lopez, A.; Pattupara, T.; Blaising, J.; Pedersen, L.; Albaek, N.; Jackerott, M.; et al. Liver-Targeted Anti-HBV Single-Stranded Oligonucleotides with Locked Nucleic Acid Potently Reduce HBV Gene Expression In Vivo. Mol. Ther. Nucleic Acids 2018, 11, 441-454. [CrossRef]

169. Sebestyen, M.G.; Wong, S.C.; Trubetskoy, V.; Lewis, D.L.; Wooddell, C.I. Targeted in vivo delivery of siRNA and an endosomereleasing agent to hepatocytes. Methods Mol. Biol. 2015, 1218, 163-186. [CrossRef]

170. Wooddell, C.I.; Rozema, D.B.; Hossbach, M.; John, M.; Hamilton, H.L.; Chu, Q.; Hegge, J.O.; Klein, J.J.; Wakefield, D.H.; Oropeza, C.E.; et al. Hepatocyte-targeted RNAi therapeutics for the treatment of chronic hepatitis B virus infection. Mol. Ther. 2013, 21, 973-985. [CrossRef]

171. Streinu-Cercel, A.; Gane, E.; Cheng, W.; Sievert, W.; Roberts, S.; Ahn, S.H.; Kim, Y.J.; Agarwal, K.; Niforos, D.; Symonds, B.; et al. A phase 2a study evaluating the multi-dose activity of ARB-1467 in HBeAg positive and negative virally suppressed subjects with hepatitis B. J. Hepatol. 2017, 66, S688-S689. [CrossRef]

172. Yuen, M.-F.; Locarnini, S.; Lim, T.H.; Strasser, S.; Sievert, W.; Cheng, W.; Thompson, A.; Given, B.; Schluep, T.; Hamilton, J.; et al. PS-080-Short term RNA interference therapy in chronic hepatitis B using JNJ-3989 brings majority of patients to HBsAg $<100$ IU/ml threshold. J. Hepatol. 2019, 70, e51-e52. [CrossRef]

173. Lee, A.C.H.; Thi, E.P.; Cuconati, A.; Ardzinski, A.; Holland, R.; Huang, H.; Kondratowicz, A.S.; Kowalski, R.; Palmer, L.; Pasetka, C.; et al. FRI-184-Function and drug combination studies in cell culture models for AB-729, a subcutaneously administered siRNA investigational agent for chronic hepatitis B infection. J. Hepatol. 2019, 70. [CrossRef]

174. Han, K.; Cremer, J.; Elston, R.; Oliver, S.; Baptiste-Brown, S.; Chen, S.; Gardiner, D.; Davies, M.; Saunders, J.; Hamatake, R.; et al. A Randomized, Double-Blind, Placebo-Controlled, First-Time-in-Human Study to Assess the Safety, Tolerability, and Pharmacokinetics of Single and Multiple Ascending Doses of GSK3389404 in Healthy Subjects. Clin. Pharmacol. Drug Dev. 2019, 8, 790-801. [CrossRef]

175. Sun, Z.; Xiang, W.; Guo, Y.; Chen, Z.; Liu, W.; Lu, D. Inhibition of hepatitis B virus (HBV) by LNA-mediated nuclear interference with HBV DNA transcription. Biochem. Biophys. Res. Commun. 2011, 409, 430-435. [CrossRef] [PubMed]

176. Qiu, L.; Fan, H.; Jin, W.; Zhao, B.; Wang, Y.; Ju, Y.; Chen, L.; Chen, Y.; Duan, Z.; Meng, S. miR-122-induced down-regulation of HO-1 negatively affects miR-122-mediated suppression of HBV. Biochem. Biophys. Res. Commun. 2010, 398, 771-777. [CrossRef]

177. Wang, S.; Qiu, L.; Yan, X.; Jin, W.; Wang, Y.; Chen, L.; Wu, E.; Ye, X.; Gao, G.F.; Wang, F.; et al. Loss of microRNA 122 expression in patients with hepatitis B enhances hepatitis B virus replication through cyclin G(1) -modulated P53 activity. Hepatology 2012, 55, 730-741. [CrossRef]

178. Chan, Y.K.; Gack, M.U. Viral evasion of intracellular DNA and RNA sensing. Nat. Rev. Microbiol. 2016, 14, 360-373. [CrossRef]

179. Lanford, R.E.; Guerra, B.; Chavez, D.; Giavedoni, L.; Hodara, V.L.; Brasky, K.M.; Fosdick, A.; Frey, C.R.; Zheng, J.; Wolfgang, G.; et al. GS-9620, an oral agonist of Toll-like receptor-7, induces prolonged suppression of hepatitis B virus in chronically infected chimpanzees. Gastroenterology 2013, 144, 1508-1517. [CrossRef]

180. Menne, S.; Tumas, D.B.; Liu, K.H.; Thampi, L.; AlDeghaither, D.; Baldwin, B.H.; Bellezza, C.A.; Cote, P.J.; Zheng, J.; Halcomb, R.; et al. Sustained efficacy and seroconversion with the Toll-like receptor 7 agonist GS-9620 in the Woodchuck model of chronic hepatitis B. J. Hepatol. 2015, 62, 1237-1245. [CrossRef]

181. Gane, E.J.; Lim, Y.S.; Gordon, S.C.; Visvanathan, K.; Sicard, E.; Fedorak, R.N.; Roberts, S.; Massetto, B.; Ye, Z.; Pflanz, S.; et al. The oral toll-like receptor-7 agonist GS-9620 in patients with chronic hepatitis B virus infection. J. Hepatol. 2015, 63, 320-328. [CrossRef]

182. Janssen, H.L.A.; Brunetto, M.R.; Kim, Y.J.; Ferrari, C.; Massetto, B.; Nguyen, A.H.; Joshi, A.; Woo, J.; Lau, A.H.; Gaggar, A.; et al. Safety, efficacy and pharmacodynamics of vesatolimod (GS-9620) in virally suppressed patients with chronic hepatitis B. J. Hepatol. 2018, 68, 431-440. [CrossRef]

183. Daffis, S.; Balsitis, S.; Chamberlain, J.; Zheng, J.; Santos, R.; Rowe, W.; Ramakrishnan, D.; Pattabiraman, D.; Spurlock, S.; Chu, R.; et al. Toll-Like Receptor 8 Agonist GS-9688 Induces Sustained Efficacy in the Woodchuck Model of Chronic Hepatitis B. Hepatology 2020. [CrossRef]

184. Mackman, R.L.; Mish, M.; Chin, G.; Perry, J.K.; Appleby, T.; Aktoudianakis, V.; Metobo, S.; Pyun, P.; Niu, C.; Daffis, S.; et al. Discovery of GS-9688 (Selgantolimod) as a Potent and Selective Oral Toll-Like Receptor 8 Agonist for the Treatment of Chronic Hepatitis B. J. Med. Chem. 2020. [CrossRef] [PubMed]

185. Sato, S.; Li, K.; Kameyama, T.; Hayashi, T.; Ishida, Y.; Murakami, S.; Watanabe, T.; Iijima, S.; Sakurai, Y.; Watashi, K.; et al. The RNA sensor RIG-I dually functions as an innate sensor and direct antiviral factor for hepatitis B virus. Immunity 2015, 42, 123-132. [CrossRef] [PubMed]

186. Giladi, H.; Ketzinel-Gilad, M.; Rivkin, L.; Felig, Y.; Nussbaum, O.; Galun, E. Small interfering RNA inhibits hepatitis B virus replication in mice. Mol. Ther. 2003, 8,769-776. [CrossRef]

187. Konishi, M.; Wu, C.H.; Wu, G.Y. Inhibition of HBV replication by siRNA in a stable HBV-producing cell line. Hepatology 2003, 38, 842-850. [CrossRef] [PubMed]

188. Ying, C.; De Clercq, E.; Neyts, J. Selective inhibition of hepatitis B virus replication by RNA interference. Biochem. Biophys. Res. Commun. 2003, 309, 482-484. [CrossRef] [PubMed]

189. Gish, R.G.; Yuen, M.F.; Chan, H.L.; Given, B.D.; Lai, C.L.; Locarnini, S.A.; Lau, J.Y.; Wooddell, C.I.; Schluep, T.; Lewis, D.L. Synthetic RNAi triggers and their use in chronic hepatitis B therapies with curative intent. Antivir. Res. 2015, 121, 97-108. [CrossRef] 
190. Yuen, M.F.; Schiefke, I.; Yoon, J.H.; Ahn, S.H.; Heo, J.; Kim, J.H.; Lik Yuen Chan, H.; Yoon, K.T.; Klinker, H.; Manns, M.; et al. RNA Interference Therapy With ARC-520 Results in Prolonged Hepatitis B Surface Antigen Response in Patients With Chronic Hepatitis B Infection. Hepatology 2019. [CrossRef]

191. Elmen, J.; Thonberg, H.; Ljungberg, K.; Frieden, M.; Westergaard, M.; Xu, Y.; Wahren, B.; Liang, Z.; Orum, H.; Koch, T.; et al. Locked nucleic acid (LNA) mediated improvements in siRNA stability and functionality. Nucleic Acids Res. 2005, 33, $439-447$. [CrossRef]

192. Soni, P.N.; Brown, D.; Saffie, R.; Savage, K.; Moore, D.; Gregoriadis, G.; Dusheiko, G.M. Biodistribution, stability, and antiviral efficacy of liposome-entrapped phosphorothioate antisense oligodeoxynucleotides in ducks for the treatment of chronic duck hepatitis B virus infection. Hepatology 1998, 28, 1402-1410. [CrossRef]

193. Billioud, G.; Kruse, R.L.; Carrillo, M.; Whitten-Bauer, C.; Gao, D.; Kim, A.; Chen, L.; McCaleb, M.L.; Crosby, J.R.; Hamatake, R.; et al. In vivo reduction of hepatitis B virus antigenemia and viremia by antisense oligonucleotides. J. Hepatol. 2016, 64, 781-789. [CrossRef]

194. Henke, J.I.; Goergen, D.; Zheng, J.; Song, Y.; Schuttler, C.G.; Fehr, C.; Junemann, C.; Niepmann, M. microRNA-122 stimulates translation of hepatitis C virus RNA. EMBO J. 2008, 27, 3300-3310. [CrossRef]

195. Lanford, R.E.; Hildebrandt-Eriksen, E.S.; Petri, A.; Persson, R.; Lindow, M.; Munk, M.E.; Kauppinen, S.; Orum, H. Therapeutic silencing of microRNA-122 in primates with chronic hepatitis C virus infection. Science 2010, 327, 198-201. [CrossRef] [PubMed]

196. Brown, R.J.P.; Tegtmeyer, B.; Sheldon, J.; Khera, T.; Todt, D.; Vieyres, G.; Weller, R.; Joecks, S.; Zhang, Y.; Sake, S.; et al Liver-expressed Cd302 and Cr11 limit hepatitis C virus cross-species transmission to mice. Sci. Adv. 2020, 6. [CrossRef] [PubMed]

197. Beaudoing, E.; Freier, S.; Wyatt, J.R.; Claverie, J.M.; Gautheret, D. Patterns of variant polyadenylation signal usage in human genes. Genome Res. 2000, 10, 1001-1010. [CrossRef]

198. Russnak, R.; Ganem, D. Sequences 5' to the polyadenylation signal mediate differential poly(A) site use in hepatitis B viruses. Genes Dev. 1990, 4, 764-776. [CrossRef] [PubMed]

199. Sudo, H.; Nozaki, A.; Uno, H.; Ishida, Y.; Nagahama, M. Interaction properties of human TRAMP-like proteins and their role in pre-rRNA 5'ETS turnover. FEBS Lett. 2016, 590, 2963-2972. [CrossRef] [PubMed]

200. Freitas, N.; Lukash, T.; Gunewardena, S.; Chappell, B.; Slagle, B.L.; Gudima, S.O. Relative Abundance of Integrant-Derived Viral RNAs in Infected Tissues Harvested from Chronic Hepatitis B Virus Carriers. J. Virol. 2018, 92. [CrossRef]

201. Yao, C.C.; Hung, C.H.; Hu, T.H.; Lu, S.N.; Wang, J.H.; Lee, C.M.; Chen, C.H. Incidence and predictors of HBV relapse after cessation of nucleoside analogues in HBeAg-negative patients with HBsAg </=200 IU/mL. Sci. Rep. 2017, 7, 1839. [CrossRef] [PubMed]

202. Mohd-Ismail, N.K.; Lim, Z.; Gunaratne, J.; Tan, Y.J. Mapping the Interactions of HBV cccDNA with Host Factors. Int. J. Mol. Sci. 2019, 20, 4276. [CrossRef] [PubMed] 